University at Buffalo School of Law

Digital Commons @ University at Buffalo School of Law

2014

\title{
Business Lobbying as an Informational Public Good: Can Tax Deductions for Lobbying Expenses Promote Transparency?
}

Michael Halberstam

Stuart G. Lazar

University at Buffalo School of Law

Follow this and additional works at: https://digitalcommons.law.buffalo.edu/journal_articles

Part of the Election Law Commons, Taxation-Federal Commons, and the Tax Law Commons

\section{Recommended Citation}

Michael Halberstam \& Stuart G. Lazar, Business Lobbying as an Informational Public Good: Can Tax Deductions for Lobbying Expenses Promote Transparency?, 13 Elec. L.J. 91 (2014).

Available at: https://digitalcommons.law.buffalo.edu/journal_articles/257

\section{C) ${ }_{\text {COPYRIGHT }}^{\text {N }}$}

This Article is brought to you for free and open access by the Faculty Scholarship at Digital Commons @ University at Buffalo School of Law. It has been accepted for inclusion in Journal Articles by an authorized administrator of Digital Commons @ University at Buffalo School of Law. For more information, please contact lawscholar@buffalo.edu. 


\title{
Business Lobbying as an Informational Public Good: Can Tax Deductions for Lobbying Expenses Promote Transparency?
}

\author{
Michael Halberstam and Stuart Lazar
}

\begin{abstract}
In this article, we link a proposed tax reform with a substantive disclosure requirement to promote the kind of "information subsidy" that serves the public interest, while mitigating-at least to some extent - the distortion that may result from the imbalance of financial resources on the business side and other institutional constraints identified in the literature. We argue that businesses that lobby should be encouraged to disclose the information that serves as a basis for their positions by allowing business taxpayers to deduct lobbying expenses, but only to the extent that the information subsidy that a taxpayer's lobbying supplies in fact educates lawmakers on policy issues. In other words, business lobbying can be considered to supply an informational public good only where such information is made available to all participants in the legislative process through full and timely publication. It cannot be said to supply an informational public good where it is inserted strategically into the legislative process at a time, and in such manner, that excludes others from using the information to assess the merits of proposed legislation or promote contrary interests.
\end{abstract}

\section{INTRODUCTION}

A WIDELY ACCEPTED ACCOUNT of corporate and business lobbying is that $\mathrm{K}$-Street serves as the Congress's back office by supplying costly information and technical expertise to legislators. ${ }^{1}$ Legislators and their staff, ${ }^{2}$ lobbyists, ${ }^{3}$ social scientists, ${ }^{4}$ and other observers-both critical and supportive
Michael Halberstam is an associate professor at State University of New York (SUNY) Buffalo Law School in Buffalo, NY. Stuart Lazar is an associate professor at SUNY Buffalo Law School in Buffalo, NY.

${ }^{1}$ See generally, Richard L. Hall and Alan V. Deardorff, Lobbying as a Legislative Subsidy, 100 Am. PoL. ScI. Rev. 69, 69 (2006) (stating that "lobbying is primarily a form of legislative subsidy - a matching grant of costly policy information, political intelligence, and labor to the enterprises of strategically selected legislators," and discussing literature); see also Frank Baumgartner, Jeffrey M. Berry, Marie Hojnacki, David C. Kimball, and Beth C. Leech, Lobbying and Public Policy Change: Who Wins, Who Loses and Why 123 (2009).

${ }^{2}$ See, e.g., The Policy Council, Changing Of The Guard: 2007 State Of The Industry For Lobbying And AdvoCACY 60-6I (2007) (more than two thirds of staffers surveyed view lobbyists as either "necessary to the process," as "collaborators," or as "educators").

${ }^{3}$ Bertram J. Levine, The Art of Lobbying: Building Trust And Selling Policy 124-26 (2009); Nicholas W. Allard, Lobbying Is An Honorable Profession: The Right To Petition And The Competition To Be Right, 19 Stanford L. \& Policy Rev. 23, 43 (2008) ("The most basic function of lobbyists is to educate legislators..."); Thomas Sussman, Lobbying, Ethical, Though Not Bound By the Common Good, in 72 Woodstock Report (Dec. 2002), available at $<$ http://www8 .georgetown.edu/centers/woodstock/resources/articles/TheEthics-of-Lobbying.html > .

${ }^{4}$ Baumgartner, supra note 1, at 123; Hall and Deardorff, supra note 1; David Austen-Smith, Interest Groups: Money, Information and Influence, in Perspectives on Public Choice: A HANDBOOK 3 I4 (1997) ("Lobbying is essentially an informational activity") (discussing literature). 
of lobbying practices ${ }^{5}$ - generally agree that lobbying serves as a kind of legislative subsidy. ${ }^{6}$ On the "subsidy theory," K-Street supplies critical information and resources that help decision makers in Congress understand and sort through complex policy issues, advocate for (or against) bills, ${ }^{7}$ and oversee the federal bureaucracy. ${ }^{8}$ As Thomas Sussman remarks, "government has become sufficiently complex that, without the information lobbyists bring to legislators, decision-making would be-at bestpoorly informed." 9

While more nuanced interpretations prevail in the descriptive and empirical political science literature, ${ }^{10}$ the view that "[l]obbying is essentially an informational activity," 11 has persistently reinforced the idea that lobbying provides a public good by educating legislators about policy and the consequences of legislation. ${ }^{12}$

In this article, we link a proposed tax reform with a substantive disclosure requirement to promote the kind of "information subsidy" that serves the public interest, while mitigating - at least to some extent - the distortion that may result from the imbalance of financial resources on the side of big business and other institutional constraints identified in the literature. We argue that businesses that lobby should be encouraged to disclose the information that serves as a basis for their positions by allowing business taxpayers to deduct lobbying expenses, but only to the extent that the information subsidy that a taxpayer's lobbying supplies in fact educates lawmakers on policy issues. ${ }^{13}$ In other words, business lobbying can be considered to supply an informational public good, only where such information is made available to all participants in the legislative process through full and timely publication. It cannot be said to supply an informational public good, where it is inserted strategically into the legislative process at a time, and in such manner, that excludes others from using the information to assess the merits of proposed legislation or promote contrary interests. ${ }^{14}$

\footnotetext{
${ }^{5}$ See, e.g., statements by U.S. Representatives Martin T. Meehan (D-MA) and Rahm Emanuel (D-IL) praising Senator Russ Feingold (D-WI) for introducing the Lobbying and Ethics Reform Act, the Senate companion to the House Lobbying and Ethics Reform Act introduced by Meehan and Emanuel: "K Street lobbyists have become the full-service "back office" of Congress. Whether arranging and funding lavish "fact-finding" trips, writing major legislation, or serving as an employment agency, special interest lobbyists are omnipresent. Professional lobbyists have grown in number and influence, and the laws haven't kept pace. Just as the McCain-Feingold-Shays-Meehan campaign finance reform put distance between donors and members of Congress, this legislation will do the same with K Street lobbyists and members of Congress."; LESSIG, REPUBLIC LosT 144 (2011) (Lobbyists on behalf of special interests do not try to convince opponents, but instead work to solidify their base and support the work of those representatives who already support their views to better advance them).

${ }^{6}$ Hall and Deardorff, supra note 1.

${ }^{7}$ Id. See also, Allard, supra note 3, at 43-44.

${ }^{8}$ David Epstein and Sharon O'Halloran, A Theory of Strategic Oversight: Congress, Lobbyists, and the Bureaucracy, $11 \mathrm{~J}$. L. \& ECON. 227, 227 (1995).

${ }^{9}$ Sussman, supra note 3; see also, Richard Briffault, The Anxiety of Influence: The Evolving Regulation of Lobbying, 13 Election L. J. 160-193 (2014).

${ }^{10}$ Hall and Deardorff, supra note 1, at 80-81 (describing several ways in which groups with large financial resources influence agendas and skew the process in favor of their interests).

${ }^{11}$ Austen-Smith, supra note 4, at 314 (citing literature).

${ }^{12}$ Infra notes 89, 116-124 and accompanying text.

${ }^{13} \mathrm{We}$ acknowledge the common wisdom that, allowing a deduction for certain lobbying expenditures, may exacerbate the

inequality between the "have" and "have nots" (i.e., the businesses that have large financial resources to allocate to the political process versus individuals and nonprofit organizations that do not have the same amounts to devote to arguing for their position. However, we do not argue that allowing business taxpayers to deduct these expenditures will increase (or decrease) the amount of lobbying that will occur. Rather, we believe that our proposal may have the effect of shifting the type of activities conducted by businesses from "bad" lobbying (i.e., that lobbying that occurs in back rooms and that provides legislators with information not available for public inspection) with "good" lobbying (i.e., information made available to the public that provides a common good and that allows those on the opposite side of an issue to evaluate and comment on the data and claims made by their adversaries). See infra note 113 and accompanying text. In addition, we note that, since the enactment of the reforms to Section 162(e) of the Internal Revenue Code made in 1993 to eliminate the lobbying deduction which had, as one of its purposes, the reduction of the power of special interest groups, the amount spent on lobbying activities have increased significantly.

${ }^{14}$ In other words, to the extent that the usefulness of information to the private sponsor depends on keeping it secret, or timing its release strategically, that information should not be viewed as a public good of the kind we should want to encourage. See Richard L. Hall and Frank W. Wayman, Buying Time: Moneyed Interests And The Mobilization Of Bias In Congressional Committees, 84 The Am. Polit. ScI. Rev. 797, 801 (Sept. 1990) for the proposition that special interests strategically focus on the committee stage where the process is often informal and subject to less scrutiny. "Indeed, a long tradition of research on subgovernments emphasizes that such clientism flourishes at the committee stage." Id.
} 
Currently lobbying communications are not publicized. We, therefore, call for the development of a third-generation online transparency mechanism ${ }^{15}$ to address the information asymmetries that characterize current institutions of congressional lobbying. ${ }^{16}$ Systems for disclosing the content of the information transmitted to legislators online have already been proposed ${ }^{17}$ and worked out in some detail. ${ }^{18}$ This article takes a first, incremental step towards establishing such disclosure as a routine practice, by incentivizing it with a specific, limited change to the Internal Revenue Code.

We suggest that deductions for certain business lobbying expenses be reinstated by returning to a formulation of Section 162(e) of the Internal Revenue Code similar to that which was in place from 1963 until $1993 .{ }^{19}$ The article argues that the current version of Section 162(e) runs counter to normative tax policy, and fails to appreciate the important role of lobbyists in satisfying legislative information sourcing in situations where the information they create or acquire can add to the public debate. Moreover, the current version of Section 162(e) may, contrary to the executive's intent at the time of its passage, have unwittingly skewed federal lobbying further in favor of large business interests and encouraged political spending by corporations. ${ }^{20}$

We argue that businesses that provide information to Congress in an open forum should be entitled to deduct (for tax purposes) the cost of providing that information as an ordinary and necessary business expense. However, the deduction should be conditioned on timely disclosure of the substantive data and policy analysis to a searchable database in standardized formats that is publicly accessible on the web. This database could be managed by the Library of Congress, which currently manages the much more limited THOMAS public information system. ${ }^{21}$

We preface our discussion with several disclaimers. First, while our focus in this article is on the nature of the information subsidy that lobbying provides to the Congress, we do not privilege this account of lobbying over all other accounts. We agree with academics ${ }^{22}$ and practitioners, ${ }^{23}$ who point out that lobbying serves different functions at different times with different players. ${ }^{24}$

\footnotetext{
${ }^{15}$ We use the term "third-generation transparency" in the sense developed by Fung et al. Archon Fung, Mary Graham, and David Weil, Full Disclosure: The Perils and Promise of Transparency (2007). See Michael Halberstam, Process Failure and Transparency Reform in Local Redistricting, 11 ELECT. L. J. 446, 466-449 (2012) (discussing the theory and its application in the redistricting context).

${ }^{16}$ The legislature is typically viewed as an institution that is separate from lobbying, even as it is recognized that lobbying is a service that is integrated into the day-to-day "production of legislation." Gregory WAWro, Legislative EntrepreneurShip In The U.S. House Of Representatives 3 (2003). We here treat the legislator and outside lobbyists as part of the same institution.

${ }^{17}$ See, e.g., Moshe Cohen-Eliya and Yoav Hammer, Lobbying and the Democratic Process, WM. AND MARY POL'y Rev., Vol. 2, No. 265, 2011 (calling for online disclosure of all written information provided to legislators). Currently, the Lobbying Disclosure Act, as amended by the Honest Leadership and Open Government Act of 2007, only requires that lobbyists, who are required to register, file disclosures of their financial activity, their clients, their campaign contributions, and the bills they lobbied on.

${ }^{18}$ See, e.g., Lee Drutman's outstanding proposal for a new online public forum for lobbyists, constituents, and other interested parties to publicly and transparently debate legislation that would be managed by the Library of Congress and provide congressional staff, journalists, and the public access to the best available arguments, information, and ideas about public policy in connection with the introduction of each piece of legislation. A Better Way to Fix Lobbying, 40 Issues In Governance

StudiEs 1 (June 2011) (published by the Brookings Institution).

${ }^{19}$ Unless otherwise provided, as used herein all references to the Code or to a section of the Code refer to the Internal Revenue Code of 1986, as amended. All references to the Regulations or to the Treasury Regulations refer to Treasury Regulations promulgated thereunder.

20 See infra note 113 and accompanying text.

21 See infra notes 147-149 and accompanying text.

${ }^{22}$ See, e.g., Timothy Lapira's discussion of the literature, Is It Who Says It, Or What They Say? Information Processing And Lobbying Influence In Congress 4-8 (Dissertation, State Univ. of N.J., Rutgers, 2008) (noting that "interest group research has traditionally approached the subject of lobbying with the assumption that groups indeed provide valuable information to politicians, but has varied in its emphasis on the theoretical nature and ultimate purpose of that information," and distinguishing three categories of theories "exchange, framing, and informational").

${ }^{23}$ We thank Craig Holman and Nick Allard for asking us to clarify our position in this regard.

${ }^{24}$ We do not infer from Hall and Deardorff's information subsidy theory that all, or even a large part, of the information lobbying provides to Congress is a public good. We argue, instead, that those who claim lobbying provides an informational public good (which Hall and Deardorff themselves do not) must, upon reflection, recognize that the current channels of information transmission cannot support this claim. In other words, we believe that, whatever position commentators take with respect to the value of information provided through the lobbying process, public information is better than information conveyed in secret.
} 
Moreover, with regard to the tax subsidy, our claim is not that the non-deductibility of lobbying expenses deters big businesses from providing substantive information to Congress or to the public, but that allowing a deduction for such expenditures could incentivize business taxpayers to publicize information that is currently exchanged behind closed doors in ways that are useful for public deliberation and the legislative process. ${ }^{25}$ On the other hand, we do suggest that the changes made to Section 162(e) in 1993, which deny a deduction for all lobbying communications (as such term is defined in the Code), may have affected the ability of small businesses to lobby Congress.

Additionally, we recognize that incentivizing substantive disclosure will not solve all of the problems associated with lobbying and the legislative process. For example, the control that lobbyists can exert over legally unlimited election spending by their large business clients in a post-Citizens United era is, in many ways, far more troubling than business lobbying expenditures in and of themselves. ${ }^{26}$ The benefits of substantive lobbying disclosure that we advocate may not make much of a difference in curing distortions of the lobbying process unless corporate political spending is reigned in. ${ }^{27}$ Moreover, even if corporate (and union) political spending is reigned in, the "gift economy," in which lawmakers provide privileged access to those citizens, businesses, and their lobbyists in exchange for contributions to legislators' reelection campaigns, or for routinely paying for expensive lunches and dinners, continues to ensure that the system does not provide equal access to all. ${ }^{28}$ We address these problems here only insofar as we seek to distinguish between direct lobbying expenditures and political spending - a distinction that the 1993 amendments to Section 162(e) have undercut. $^{29}$

Furthermore, we acknowledge that lobbyists do much more than provide information to Congress. They keep clients informed about legislative and regulatory developments, engage in administrative lobbying, pursue grassroots lobbying efforts, and much more. ${ }^{30}$ Our analysis is restricted to direct lobbying of Congress, and only one problem of the information exchange that takes place.

Finally, we note that this article contributes to a long and complicated debate regarding the cor- rect mechanism to open up the process of information sourcing by Congress, including proposals to publish the reports created by the Congressional Research Service (which are secret by default), ${ }^{31}$ calls for close to real-time publication of all information about all bills at each stage in the legislative process, ${ }^{32}$ and attempts to force legislators back into their offices on Capitol Hill by eliminating free lunches and other boondoggles that rendered them inaccessible to those without the financial

${ }^{25}$ In other words, taking the deduction is voluntary, but requires additional steps to comply with the transparency regulation. Our proposal thus advances a change in the current "choice architecture" that lumps legislative lobbying together with grassroots lobbying and political spending from the perspective of the taxpayer. Richard H. Thaler AMD CASS R. Sunstein, Nudge: Improving Decisions About Health, Wealth, AND HAPPINESS (2008).

${ }^{26}$ See Craig Holman, The Tension Between Lobbying and Campaign Finance Laws: Rolling Back Gains Made Under the Honest Leadership and Open Government Act of 2007, 13 ELECT. L. J. 45-74 (2014) describing the damage the Supreme Court's decision in Citizens' United v. Federal Election Commission, 558 U.S. 310 (2010) to the gains made by the Honest Leadership and Open Government Act of 2007; Tolchin AND Tolchin, Pinstripe Patronage: Political Favoritism From the Clubhouse to the White House and Beyond 89 (2010) ("Lobbyists and members of Congress often become tied to each other through relationships based on mutual favors. These ties have become much stronger in recent years as election 'reform' necessitates more and more fundraising interdependence").

${ }^{27}$ The extent of involvement that some corporations have in elections at the federal, state, and local level is described in Town in Iowa Discovers There Is No Election Too Small For Big Political Groups Seeking Influence, Washington Post (Oct. 31, 2013) available at < http://www.washingtonpost.com/ national/iowa-town-discovers-that-no-election-is-too-small-forbig-political-groups-seeking-influence/2013/10/31/30ba7ab84247-11e3-b028-de922d7a3f47_story.html > .

${ }^{28}$ See LeSsig, supra note 5, at $142 \mathrm{ff}$ and $166 \mathrm{ff}$ (2012) (discussing the literature); Clayton D. Peoples, Contributor Influence in Congress: Social Ties and PAC Effects on U.S. House Policymaking, 51 SocIOLOGICAL QUART. 649 (2010).

${ }^{29}$ But we leave a full motivation of this distinction to a separate article.

${ }^{30}$ See Allard, supra note 3, at 46.

${ }^{31}$ See, e.g., H.Res. 110: Congressional Research Service Electronic Accessibility Resolution of 2013 introduced by Rep. Leonard Lance.

${ }^{32}$ GovTrack.us, run by Josh Tauberer, now scours many different government websites to compile much more information about bills and the legislative process than the Library of Congress's Thomas system provides. See, e.g., Joshua Tauberer, Case Study: GovTrack.us in Timothy O'Reilly, Et. Al., Open Government 201 (2010). 
resources to participate in the pay-to-play process. ${ }^{33}$ We believe, however, that our article breaks new ground by (1) recognizing that lobbying information does not provide a public good unless published, and (2) introducing a mechanism to promote transparency in the legislative process by incentivizing lobbyists to disclose publicly information that legislators have consistently used (though not revealed) in making legislative decisions.

Part II describes the current tax treatment for lobbying expenses, specifically Section 162(e), which denies a deduction of direct lobbying expenses. Part III describes the evolution of Section 162(e), which has morphed, over time, from the position under common law that no lobbying expenses should be deductible, to the version in effect from 1963 until 1993 that allowed a deduction for certain direct lobbying expenses, to the revised version enacted in 1993 that scaled back the deductibility of these expenditures. Part IV critically examines the arguments that support the current version of Section 162(e) from a tax perspective. Part V considers the claim that lobbying provides an informational public good in greater detail and specifies how generally recognized information asymmetries and strategic uses of lobbying information detract from the legislative process. Part VI explores our proposal in greater depth. The article concludes with Part VII.

\section{INTRODUCTION TO THE TAX PROVISION}

Section 162(a) provides taxpayers (including large corporations) with a deduction for "ordinary and necessary" expenses paid or incurred in carrying on a trade or business. In other words, a business is entitled to reduce its revenue by the expenses it incurs to generate that revenue in determining taxable income. Lobbying and political expenditures, however, currently are not deductible. Section 162(e)(1) provides, in full:

(e) Denial of deduction for certain lobbying and political expenditures

(1) In general

No deduction shall be allowed under subsection (a) for any amount paid or incurred in connection with-

(A) influencing legislation,
(B) participation in, or intervention in, any political campaign on behalf of (or in opposition to) any candidate for public office,

(C) any attempt to influence the general public, or segments thereof, with respect to elections, legislative matters, or referendums, or (D) any direct communication with a covered executive branch official in an attempt to influence the official actions or positions of such official.

We emphasize that, in this article, we only propose an amendment to Section 162(e)(1)(A), regarding the denial of a deduction for "influencing legislation," but do not consider any of the other disallowances.

\section{A. Scope}

There is no single definition in the law for the term "lobbying." 34 For purposes of disallowing a business expense deduction, the term "lobbying" includes "influencing legislation," which is defined in the statute as "any attempt to influence legislation through communication with any member or employee of a legislative body, or with any government official or employee who may participate in the formulation of legislation." 35 Moreover, any amounts paid or incurred for research for, or preparation, planning, or coordination of, any of these activities is treated as a lobbying activity, and also is disallowed as a deduction. ${ }^{36}$ The regulations provide that influencing legislation means: (A) any attempt to influence any legislation through a lobbying communication, and (B) all activities, such

\footnotetext{
${ }^{33}$ The Honest Leadership and Open Government Act of 2007, Pub. L. No. 110-81, 121 Stat. 735, enacted September 14, 2007, prohibited gifts, free lunches, transportation, and other benefits conferred on legislators in Congress by lobbyists. Holman, see supra note 26.

${ }^{34}$ See Lloyd Hitoshi Mayer, What Is This "Lobbying" That We Are All So Worried About?, 26 Yale L. \& Pol'y Rev. 485, 487-488 (2008).

${ }^{35}$ I.R.C. $\S 162(\mathrm{e})(4)(A)$. For these purposes, the term "legislation" includes action with respect to Acts, bills, resolutions, or similar items by the Congress, any State legislature, any local council, or similar governing body, or by the public in a referendum, initiative, constitutional amendment, or similar procedure. I.R.C. $\S 4911(\mathrm{e})(2)$.

${ }^{36}$ I.R.C. $\S$ 162(e)(5)(C). In addition, Section 162(e) denies a deduction for the portion of dues or similar amounts paid by a taxpayer to a tax-exempt organization that is allocable to the expenditures set forth in Section 162(e)(1). I.R.C. $\S 162(\mathrm{e})(3)$.
} 
as research, preparation, planning and coordination, including deciding whether to make a lobbying communication, engaged in for the purpose of making or supporting a lobbying communication, even if it is not made. ${ }^{37}$ The regulations provide that an attempt to influence any legislation through a lobbying communication is making a lobbying communication. $^{38}$

For these purposes, a "lobbying communication" is a communication (other than any communication compelled by subpoena, or otherwise compelled by federal or state law) with any member or employee of a legislative body or any other government official or employee, who may participate in the formulation of the legislation, that does either of the following: (A) the communication refers to specific legislation and reflects a view on that legislation; or (B) the communication clarifies, amplifies, modifies, or provides support for views reflected in a prior lobbying communication. ${ }^{39}$ Specific legislation includes both pending legislation and legislation that has not yet been introduced. $^{40}$

The language of the regulations is critical in that it takes into account communications that reflect the writer's view on legislation in addition to communications that either expressly support or oppose that legislation. According to the preamble to the regulations, several commentators suggested that the regulations should distinguish between influencing legislation and educating legislators. In addition, some commentators suggested that presenting a balanced analysis of the merits and defects of specific legislation should not constitute reflecting a view on legislation. However, neither recommendation was adopted in the final regulations. ${ }^{41}$

By broadly defining the term "influencing legislation," Treasury Regulations promulgated under Section 162(e) disallow a deduction for much of the industry information that might serve a public good. The following examples, extracted from these regulations, illustrate the scope of such term:

Example 8. (i) Taxpayer Y represents citrus fruit growers. $\mathrm{Y}$ writes a letter to a United States senator discussing how pesticide $\mathrm{O}$ has benefited citrus fruit growers and disputing problems linked to its use. The letter discusses a bill pending in Congress and states in part:
This bill would prohibit the use of pesticide $\mathrm{O}$. If citrus growers are unable to use this pesticide, their crop yields will be severely reduced, leading to higher prices for consumers and lower profits, even bankruptcy, for growers.

(ii) Y's views on the bill are reflected in this statement. Thus, the communication is a lobbying communication, and $\mathrm{Y}$ is influencing legislation. $^{42}$

Example 9. (i) B, the president of Taxpayer Z, an insurance company, meets with $Q$, who chairs the $\mathrm{X}$ state legislature's committee with jurisdiction over laws regulating insurance companies, to discuss the possibility of legislation to address current problems with surplusline companies. B recommends that legislation be introduced that would create minimum capital and surplus requirements for surplus-line companies and create clearer guidelines concerning the risks that surplus-line companies can insure. B's discussion with $\mathrm{Q}$ is a lobbying communication because $B$ refers to and reflects a view on a specific legislative proposal. Therefore, $\mathrm{Z}$ is influencing legislation.

(ii) Q is not convinced that the market for surplus-line companies is substantial enough to warrant such legislation and requests that $\mathrm{B}$ provide information on the amount and types of risks covered by surplus-line companies.

\footnotetext{
${ }^{37}$ Treas. Reg. $\S 1.162-29$ (b)(1) (as amended in 1995).

${ }^{38}$ Treas. Reg. $\S 1.162-29$ (b)(2) (as amended in 1995).

${ }^{39}$ Treas. Reg. § 1.162-29(b)(3) (as amended in 1995).

${ }^{40}$ Treas. Reg. $\S 1.162-29$ (b)(5) (as amended in 1995). The regulations provide an example in which a taxpayer prepares a paper asserting that a lack of new capital is hurting the national economy. The paper indicates that lowering the capital gains rate would increase the availability of capital and increase tax receipts from the capital gains tax. The taxpayer forwards the paper to representatives in Congress with a cover letter that, in part, urges that those representatives support a reduction in the capital gains tax rate. This communication is a lobbying communication because it refers to and reflects a view on a specific legislative proposal (i.e., lowering the capital gains rate). The example concludes that the taxpayer is influencing legislation even though there is no indication that Congress previously had been considering any proposal with respect to the capital gains rate. See Treas. Reg. 1.162-29(b)(7) (as amended in 1995), Ex. 5.

${ }^{41}$ T.D. 8602, 60 Fed. Reg. 37,568 (July 21, 1995).

${ }^{42}$ Treas. Reg. 1.162-29(b)(7) (as amended in 1995), Ex. 8. The conclusion of this example is that Y's expenses in preparing the communication would not be deductible for tax purposes.
} 
After the meeting, B has employees of $\mathrm{Z}$ prepare estimates of the percentage of property and casualty insurance risks handled by surplus-line companies. B sends the estimates with a cover letter that simply refers to the enclosed materials. Although B's follow-up letter to Q does not refer to specific legislation or reflect a view on such legislation, B's letter supports the views reflected in the earlier communication. Therefore, the letter is a lobbying communication and $\mathrm{Z}$ is influencing legislation. ${ }^{43}$

In both cases, one can certainly see the benefit to the taxpayer that could result from the success of its own lobbying efforts. But there is also a public benefit to such information provided by the business taxpayer. Knowledge of markets, business conditions, and the effects of government action on thousands of different industries across the country (with customers and production facilities around the globe) are essential to the intelligent regulation of markets. ${ }^{44}$ Those who believe in market regulation should be particularly concerned that legislators have ready access to such independent information for purposes of legislation and oversight. ${ }^{45}$

We acknowledge that information produced by the type of lobbying described in Examples 8 and
9, above, may be self-serving. But this suggests all the more that routine publication should be encouraged. Legislators presently already rely on information provided by lobbyists. By bringing this information to light, state and local governments, the press, sophisticated intermediaries, and the public-who may be on the other side of an issue - are empowered to participate in fact-checking, interpreting, and counterbalancing one-sided information. Moreover, by publishing lobbying communications, the judgment as to how some piece of information communicated privately to a committee chair or staffer should be interpreted, or whether it should become part of the debate at all, is not left to the judgment of individual legislators themselves. ${ }^{46}$

\section{B. Justification}

The non-deductibility provisions of Section 162(e) have been justified on a number of grounds. First, lobbying expenditures are not sufficiently related to a business's survival and profitability to fall within the "ordinary and necessary" requirement of Section $162 .{ }^{47}$ Second, in an attempt to achieve "tax neutrality" 48 with respect to lobbying and political expenditures, business taxpayers should not be entitled to a tax benefit (i.e. the deduction) not available to non-business taxpayers. ${ }^{49}$ Finally, non-deductibility reflects a public policy

\footnotetext{
${ }^{43}$ Treas. Reg. 1.162-29(b)(7) (as amended in 1995), Ex. 9. Again, the conclusion of this example is that Z's expenses in preparing the communication would not be deductible for tax purposes.

${ }^{44}$ See, e.g., Joseph E. Stiglitz, Information and the Change in Paradigm in Economics in Selected Works Of Joseph StIGLITZ, VOL. I 53, 62ff (2009) (criticizing the standard, competitive, general equilibrium approach to market failure, because it did not account "for the myriad information problems faced by consumers and firms every day...").

${ }^{45}$ By "independent" we here mean independent of the executive and administrative agencies. As the ABA Taskforce on Federal Lobbying Laws notes, " $[t]$ he government-whether it be the executive or the legislative branch-simply cannot know the intricate details of the myriad aspects of national life that its actions might affect unless it has access to the expert contributions of the persons and interests involved." Lobbying Law in the Spotlight: Challenges and Proposed Improvements, available at < http://www.americanbar.org/content/dam/aba/migrated/ 2011_build/administrative_law/lobbying_task_force_report_ 010311.authcheckdam.pdf $>$.

${ }^{46}$ While committee chairs, committee staff, and policy experts among legislators may have access to information on both sides of an issue, other legislators, not as well versed in that policy area, may only see information that is publicly disclosed in a

timely fashion. By incentivizing the release of additional public information, these legislators may become more informed about more issues upon which they cast votes. See notes 139 144 and accompanying text. See, e.g., Robert G. KAISER, Act of Congress: How America's Essential Institution Works, AND How IT DoESN'T (2013) (describing how important decisions on mark-up were sometimes conducted by committee staff without input by legislators).

${ }^{47}$ See, infra, Part III. See also Comment, Deducting Business Expenses Designed to Influence Governmental Policy as "Ordinary and Necessary": Cammarano v. United States and a Bit Beyond, 69 YALE L.J. 1017, 1028 (1960).

${ }^{48}$ One commentator expressed the view that the "no subsidy of lobbying" rationale might express one of three different concerns of tax neutrality: (1) the government should not be both an encourager and recipient of lobbying (judicial neutrality), (2) these lobbying deductions are discriminatory because they are worth more to wealthier taxpayers (wealth neutrality), and (3) all taxpayers, especially those who cannot obtain lobbying deductions, should be treated equally (deduction neutrality). See Jasper L. Cummings, Jr., Tax Policy, Social Policy, and Politics: Amending Section 162(e), 61 Tax Notes 595, 604 (Nov. 1, 1993).

${ }^{49}$ Cammarano v. U.S., 353 U.S. 498 (1959).
} 
concern embodied in many state laws prohibiting corporate spending for political purposes. ${ }^{50}$ Tax consequences, it is urged, must not frustrate sharply defined national or state policies proscribing particular types of conduct. ${ }^{51}$

As we discuss in Part IV, each of these arguments is problematic-either from a pure tax standpoint, or from a larger public policy standpoint.

\section{The local exception}

Section 162(e) also contains a surprising exception. While lobbying at the federal and state legislative levels are non-deductible, Section 162(e)(2) makes an exception "in the case of any legislation of any local council or similar governing body." For local government lobbying, the relevant provision does allow the deduction of:

all ordinary and necessary expenses (including, but not limited to, traveling expenses described in subsection (a)(2) and the cost of preparing testimony) paid or incurred during the taxable year in carrying on any trade or business-

(i) in direct connection with appearances before, submission of statements to, or sending communications to the committees, or individual members, of such council or body with respect to legislation or proposed legislation of direct interest to the taxpayer, or (ii) in direct connection with communication of information between the taxpayer and an organization of which the taxpayer is a member with respect to any such legislation or proposed legislation which is of direct interest to the taxpayer and to such organization... 52

In other words, ordinary and necessary expenses incurred in connection with direct (not grass roots) local legislative communications, or communications regarding local legislative matters between a taxpayer and a trade association of which the taxpayer is a member, are deductible. ${ }^{53}$

This exception is truly puzzling. Indeed, leaving aside that this deduction is available to small businesses as well-the "local exception" could look like a federal subsidy to large corporations for influencing local legislation-if you accept the argument that a tax deduction constitutes a "subsidy." 54 Multi-national corporations can already bring overwhelming lobbying resources to bear against resistance to their plans at the local legislative level. Moreover, their bargaining position for tax deductions with municipalities is already lopsided, in that municipalities cannot afford to lose jobs and must attract new industry. If anything, the Code should not further encourage outside influence at the local level by big business.

So what explains the disallowance under Section 162(e)(1)(A) and the "local exception" under Section 162(e)(2)? As we shall see, the local exception is primarily a survival from the original 1963 statute that, for the first time, explicitly allowed for the deductibility of direct lobbying expenses at all levels of government.

\section{PATH DEPENDENCE, POLITICS, AND POLICY}

The history of Section 162(e) represents a fractious debate on the issue, and several policy changes, with a persistent bias against allowing businesses to expense their lobbying costs.

\footnotetext{
${ }^{50}$ With the Supreme Court's decision in Citizens' United, this picture has become slightly more complicated. We acknowledge that, by allowing businesses to deduct expenditures for certain lobbying expenses, there is the possibility that businesses will have a greater incentive to devote resources towards lobbying. However, there is no evidence that the reforms to Section 162(e) that disallowed a deduction for all lobbying expenditures had any effect in reducing the amount spent by business on lobbying activities. Conversely, we do not believe that allowing a deduction for lobbying activities will increase the extent that businesses lobby their positions. Instead, we argue that, on the question of deductibility, the issue of salience arises in the types of lobbying activities conducted. We believe that there is a low degree of correlation between the amount of lobbying and the availability of a tax deduction for lobbying. Rather, we believe that allowing a business expense deduction for certain types of lobbying, while continuing to disallow a deduction for other types of lobbying, will incentivize those businesses active in the lobbying process to change their behavior by disclosing information previously provided to legislators (and used in making voting decisions) in camera because of the added tax benefits.

${ }^{51}$ Commissioner v. Heininger, 320 U.S. 467, 473 (1943) (legal expenses incurred in resisting issuance by Postmaster General of fraud order accorded deductibility). See Cammarano $v$. United States, 358 U.S. 498, 508 (1959); Tank Truck Rentals, Inc. v. Commissioner, 356 U.S. 30, 33-34 (1958); Lilly v. Commissioner, 343 U.S. 90, 94-97 (1952).

${ }^{52}$ I.R.C. $\S 162(\mathrm{e})(2)$

${ }^{53}$ I.R.C. $\S 162(\mathrm{e})$.

${ }^{54}$ See, generally, Theodore Seto, Keeping Tax-Subsidized Corporate Money Out Of Politics, 127 Tax Notes 1476 (June 28, 2010).
} 


\section{A. The U.S. Treasury's disallowance and the interpretation of the judiciary: Pre-1963 views of the deduction for lobbying expenditures}

Prior to 1962, the general rule was that expenses to influence legislation were not deductible. Jasper Cummings has argued that disallowance was the result of long-standing judicial disfavor of certain types of lobbying activities. ${ }^{55}$ Thus, in Trist $v$. Child (1874), the Supreme Court refused to enforce a contract for payment for lobbying services on grounds that the contract violated public policy. ${ }^{56}$ The Supreme Court's language reflects the profound distaste with which much of the federal judiciary has regarded lobbying throughout most of modern American history. The Trist Court stated:

The agreement in the present case was for the sale of the influence and exertions of the lobby agent to bring about the passage of a law for the payment of a private claim, without reference to its merits, by means which, if not corrupt, were illegitimate, and considered in connection with the pecuniary interest of the agent at stake, contrary to the plainest principles of public policy. No one has a right, in such circumstances, to put himself in a position of temptation to do what is regarded as so pernicious in its character. The law forbids the inchoate step, and puts the seal of its reprobation upon the undertaking.

If any of the great corporations of the country were to hire adventurers who make market of themselves in this way, to procure the passage of a general law with a view to the promotion of their private interests, the moral sense of every right-minded man would instinctively denounce the employer and employed as steeped in corruption, and the employment as infamous. ${ }^{57}$

For federal income tax purposes, non-deductibility of lobbying expenses began early in the process. The corporate income tax was enacted in 1909, the individual income tax in 1913, and, by, 1915, the Treasury Department had issued an administrative ruling concluding that lobbying expenditures "are held not to be ordinary and necessary expenses

\footnotetext{
${ }^{55}$ See Cummings, supra note 48 , at 605-607.

${ }^{56} 88$ U.S. 441 (1874).

${ }^{57}$ Id. at $451-452$. The Court continued:
}

If the instances were numerous, open, and tolerated, they would be regarded as measuring the decay of the public morals and the degeneracy of the times. No prophetic spirit would be needed to foretell the consequences near at hand. The same thing in lesser legislation, if not so prolific of alarming evils, is not less vicious in itself, nor less to be condemned. The vital principle of both is the same. The evils of the latter are of sufficient magnitude to invite the most serious consideration. The prohibition of the law rests upon a solid foundation. A private bill is apt to attract little attention. It involves no great public interest, and usually fails to excite much discussion. Not unfrequently the facts are whispered to those whose duty it is to investigate, vouched for by them, and the passage of the measure is thus secured. If the agent is truthful, and conceals nothing, all is well. If he uses nefarious means with success, the spring-head and the stream of legislation are polluted. To legalize the traffic of such service, would open a door at which fraud and falsehood would not fail to enter and make themselves felt at every accessible point. It would invite their presence and offer them a premium. If the tempted agent be corrupt himself, and disposed to corrupt others, the transition requires but a single step. He has the means in his hands, with every facility and a strong incentive to use them. The widespread suspicion which prevails, and charges openly made and hardly denied, lead to the conclusion that such events are not of rare occurrence. Where the avarice of the agent is inflamed by the hope of a reward contingent upon success, and to be graduated by a percentage upon the amount appropriated, the danger of tampering in its worst form is greatly increased.

It is by reason of these things that the law is as it is upon the subject. It will not allow either party to be led into temptation where the thing to be guarded against is so deleterious to private morals and so injurious to the public welfare. In expressing these views, we follow the lead of reason and authority.

We are aware of no case in English or American jurisprudence like the one here under consideration, where the agreement has not been adjudged to be illegal and void. We have said that for professional services in this connection a just compensation, may be recovered. But where they are blended and confused with those which are forbidden, the whole is a unit and indivisible. That which is bad destroys that which is good, and they perish together. Services of the latter character, gratuitously rendered, are not unlawful. The absence of motive to wrong is the foundation of the sanction. The tendency to mischief, if not wanting, is greatly lessened. The taint lies in the stipulation for pay. Where that exists, it affects fatally, in all its parts, the entire body of the contract. In all such cases, protior conditio defendentis. Where there is turpitude, the law will help neither party.

$I d$. at $451-452$. 
in the operation and maintenance of the business of a corporation and are therefore not deductible." ${ }^{58}$ In 1918 , also relying on the "ordinary and necessary" requirement to the predecessor to Section 162, the Treasury Department enacted a regulation denying a deduction for lobbying expenditures. ${ }^{59}$

Even as Treasury denied a deduction for lobbying activities, during the 1920s and 1930s, the Board of Tax Appeals (i.e., the predecessor to the Tax Court), nonetheless, frequently allowed taxpayers to deduct the costs of lobbying on a case-by-case basis. The Board has been described as a "formidable foe" to the Treasury's policy during this period. ${ }^{60}$ According to Professor Sharp, "[t]o avoid the obligatory application of the regulation, that tribunal chose a singular approach. The Board considered the facts in each particular case and reached its conclusion solely by determining whether or not the expenditures were in fact ordinary and necessary." 61

The Supreme Court first considered the Treasury Regulations in Textile Mills Securities Corp. v. Commissioner (1941). ${ }^{62}$ That case involved a taxpayer who represented German textile interests in an effort to obtain legislation regarding properties seized during World War I. ${ }^{63}$ The taxpayer deducted expenses incurred in lobbying Congress to pass such legislation. The government, on audit, denied these deductions. In the absence of a statutory provision explicitly governing the deductibility of lobbying expenditures, the Court's decision hinged on Treasury's interpretation of the phrase "ordinary and necessary" business expenses. The taxpayer challenged Treasury's interpretation, maintaining that his lobbying expenses were, in fact, "ordinary and necessary." In an opinion authored by Justice Douglas-whose expertise in corporate finance and administrative law was beyond challenge ${ }^{64}$ the Court upheld the Treasury Department's regulations by construing Congress's delegation of powers broadly, stating that " $[\mathrm{t}]$ he words 'ordinary and necessary' are not so clear and unambiguous in their meaning and application as to leave no room for an interpretative regulation." 65 The Court found that the Treasury Department had not "usurped the legislative function by carving out this special group of expenses and making them non-deductible." Moreover, the Court reasoned, "[s]uch a course did not contravene any Congressional policy.

\footnotetext{
${ }^{58}$ See T.D. 2137,17 Treas. Dec. Int. Rev. 57, 57-58 (1915).

the statute was sufficiently ambiguous and that, because ${ }^{59}$ Treas. Reg. $\S 33$, art. 143 (1918), reprinted in I32 INTERNAL Revenue Acts of the United States, i909-I950: Legislative Histories, Laws, AND Administrative DocuMENTS 75 (Bernard D. ReAms, JR. ED., I979). The regulation, promulgated under the charitable contributable deduction provisions, provided that: "Corporations are not entitled to deduct from gross income contributions or gifts which individuals may deduct under section 23(n). Donations made by a corporation for purposes connected with the operation of its business, however, when limited to charitable institutions, hospitals, or educational institutions conducted for the benefit of its employees or their dependents are a proper deduction as ordinary and necessary expenses. Donations which legitimately represent a consideration for a benefit flowing directly to the corporation as an incident of its business are allowable deductions from gross income...Sums of money expended for lobbying purposes, the promotion or defeat of legislation, the exploitation of propaganda, including advertising other than trade advertising, and contributions for campaign expenses, are not deductible from gross income (emphasis added)."

${ }^{60}$ See generally Dean E. Sharp, Reflection on the Disallowance of Income Tax Deductions for Lobbying Expenditures, 39 B.U. L. REv. 365, 367-8 (1959).

${ }^{61}$ Id. at 367-368, n. 15 and 16. The Board of Tax Appeals first reversal came in the Ninth Circuit with Sunset Scavenger Co. v. Commissioner, 84 F.2d 453 (9th Cir. 1936), rev'g. 31 B.T.A. 758 (1934). In that case, the court concluded that the term "ordinary and necessary" as used in Congress had re-enacted the statute with the knowledge of the regulation [denying a deduction for lobbying expenses], such re-enactment was an implicit blessing that "the regulation was not inconsistent with the intent of the statute." Id., citing Massachusetts Mutual Life Ins. Co. v. United States, 288U.S. 269, 273, 53 S.Ct. 337, 339, 77 L.Ed. 739. The Board of Tax Appeals rejected the Ninth Circuit's view and continued to deny the obligatory application of the regulations. See Sharp at 368, n. 22, citing William P. Kyne, 35 B.T.A. 202 (1936); Lelia S. Kirby, 35 B.T.A. 578 (1936); H. R. Cullen, 41 B.T.A. 1054 (1940)

${ }^{62} 314$ U.S. 327 (1941).

${ }^{63}$ In this case, the taxpayer's compensation for these services was contingent, and the taxpayer bore all of its own expenses including the costs of lobbying (within the meaning of the regulations) on behalf of its clients. In its decision, the Court addressed two arguments by the taxpayer. First, that the regulations were inapplicable to deny a business expense for lobbying expenditures because the regulations were incorporated into the charitable deduction section for individuals rather than the business expense deduction provisions. The Court held that, based on the history of the regulations, the fact that such regulations were not incorporated under the correct provision was "frivolous." Id. at 338. The Court also held that the taxpayer's second argument, that the regulations were invalid, also lacked substance. Id.

${ }^{64}$ Douglas was drafted by Roosevelt to build the new Securities Exchange Commission in the 1930s.

${ }^{65} \mathrm{Id}$.
} 
Contracts to spread such insidious influences through legislative halls have long been condemned."66

In 1959, the Supreme Court upheld essentially the same Treasury regulation in Cammarano $v$. U.S. ${ }^{67}$ In Cammarano, the taxpayers ${ }^{68}$ deducted amounts paid to trade associations for grassroots lobbying to defeat proposed state ballot initiative measures [in Washington State and Arkansas] which would have changed the manner in which alcohol was sold in their states, significantly affecting the taxpayers' businesses. The Court saw no merit in limiting the holding in Textile Mills to direct dealings with legislators, finding that the definition of lobbying includes "publicity directed to the general public on legislative matters." 69 The Court stated " $[\mathrm{w}] \mathrm{e}$ think that initiatives are plainly 'legislation' within the meaning of these Regulations. Had the measures involved in these cases been passed by the people of Washington and Arkansas they would have had the effect and status of ordinary laws in every respect. The Constitutions of the States of Washington and Arkansas both explicitly recognize that in providing for initiatives they are vesting legislative power in the people." 70

The Court again addressed the validity of the Treasury Regulations. The taxpayers argued that their expenditures were necessary to preserve their businesses, such amounts should be deductible as ordinary and necessary business expenses under the Code as a matter of law, and a regulation purporting to deny deductibility to such expenditures is plainly contrary to the statute and ipso facto invalid. ${ }^{71}$ In affirming its holding in Textile Mills. The court further limited its holding in Heininger, which allowed a deduction for expenditures without which a business enterprise would inevitably suffer
${ }^{66} I d$. Interestingly, Textile Mills was decided on December 8, 1941 - the day after the Japanese bombed Pearl Harbor, signifying the point at which the United States entered World War II. It is hard to believe that the decision could have been decided any other way in light of the historical events affecting the nation at this time.

Textile Mills was later cited by the Supreme Court in Tank Truck Rentals, Inc. v. Commissioner, 356U.S. 30 (1958), for the proposition that a deduction may be denied under Section 162 where such deduction would frustrate public policy. Tank Truck Rentals was the basis for Congress' later enactment of Sections 162(c), (f), and (g). The legislative history to those provisions state:

From the standpoint of tax policy, there generally has been a reluctance to deny business expenses on the ground that this departs from the concept of a tax imposed on actual net business income." There still remains, however, the question as to what is an ordinary and necessary business expense. The Supreme Court in the Tank Truck Rental case, for example, in holding that the payment of fines could not be considered as ordinary and necessary, stated:

A finding of 'necessity' cannot be made however, if allowance of the deduction would frustrate sharply defined national or State policies proscribing the particular types of conduct evidenced by some governmental declaration thereof.

On the same grounds, it appears appropriate to deny deductions for bribes, illegal kickbacks, and the penalty portion of antitrust treble damage payments. A 1958 amendment to the Internal Revenue Code already suggests such a congressional policy. Under that amendment no deduction may be taken for payments to officials or employees of a foreign government if in the United States such payments would be unlawful. In addition, deduction of expenditures made to influence legislation are already limited by a spe- cific provision (sec. 162(e)) added by the Revenue Act of 1962.

Explanation of provision-The Provision added by the committee amendments denies deductions of four types of expenditures: fines or similar penalties paid to a government for the violation of any law, a portion of treble damage payments under the antitrust laws following a related criminal conviction (or plea of equity or nolo contendere), deductions for bribes paid to public officials (whether or not foreign officials), and other unlawful bribes or 'kickbacks.' The provision for the denial of the deduction for payments in these situations which are deemed to violate public policy is intended to be all inclusive. Public policy, in other circumstances, generally is not sufficiently clearly defined to justify the disallowance of deductions. However, this is not, of course, intended to affect the treatment of lobbying expenditures which are already covered by the tax law.

S. ReP. No. 552, 91st Cong., 1st Sess. 274 (1969), 1969-3 C.B. 423, 596-597.

${ }^{67}$ Cammarano v. U.S., 358 U.S. 498 (1959).

${ }^{68}$ Although jointly decided, this decision reflects two cases brought to the Court presenting identical issues for appeal: Cammarano v. U.S., 246F.2d 751 (9th Cir. 1957) and F. Strauss \& Son, Inc., of Arkansas v. Commissioner, 251F.2d 724 (8th Cir. 1958).

${ }^{69} I d$. at 505, citing e.g., Revere Racing Ass'n v. Scanlon, 232F.2d 816 (1st Cir. 1956); American Hardware \& Equipment Co. v. Commissioner, 202F.2d 126 (4th. Cir. 1953); Roberts Dairy Co. v. Commissioner, 195F.2d 948 (8th. Cir. 1952); Sunset Scavenger Co. v. Commissioner, 84F.2d 453 (9th. Cir 1936). ${ }^{70} I d$. at $505-06$.

${ }^{71} I d$. at 507. The taxpayers relied on Commissioner v. Heininger, 320U.S. 467 (1943), in which the Court held that a dentist could deduct (as ordinary and necessary business expenses) the cost of attorney's fees paid to defend himself against mail fraud charges that would have ended his business. 
adverse effects in situations where granting such deduction would frustrate no "sharply defined national or state policies." 72 However, in the case of the grassroots lobbying expenditures at issue in Cammarano, the Court noted that "[h]ere the deductions sought are prohibited by Regulations which themselves constitute an expression of a sharply defined national policy, further demonstration of which may be found in other sections of the Internal Revenue Code." 73

The Court then cited to the history on the regulations, the large body of case law, and the changes made to the Internal Revenue Code in the intervening years. Based on the fact that Congress re-enacted, without change, the term "ordinary and necessary" in the 1954 Code, the Court concluded " $[u]$ nder these circumstances we think that the Regulations have acquired the force of law." 74

Finally, turning to the issue of tax neutrality, the Court, citing Judge Learned Hand's opinion in Slee ${ }^{75}$ and amendments to the Code limiting the ability of tax-exempt organizations to engage in political or lobbying activities, attempted to illustrate that by denying the deduction at issue, all taxpayers must be treated equally with respect to these expenditures. "Controversies of that sort must be conducted without public subvention; the Treasury stands aside from them." 76 In other words, the Court was refusing to allow the fisc to subsidize lob- bying expenditures and to require their payment with after-tax dollars.

In its opinion, the Court appears to combine this with Cammarano's argument that the limitation of a tax deduction is the equivalent of a limitation of their First Amendment rights. ${ }^{77}$ The Court rejected this argument stating:

Petitioners are not being denied a tax deduction because they engage in constitutionally protected activities, but are simply being required to pay for those activities entirely out of their own pockets, as everyone else engaging in similar activities is required to do under the provisions of the Internal Revenue Code. Nondiscriminatory denial of deduction from gross income to sums expended to promote or defeat legislation is plainly not "aimed at the suppression of dangerous ideas." ... Rather, it appears to us to express a determination by Congress that since purchased publicity can influence the fate of legislation which will affect, directly or indirectly, all in the community, everyone in the community should stand on the same footing as regards its purchase so far as the Treasury of the United States is concerned. ${ }^{78}$

Following Cammarano, the Treasury Department promulgated regulations that expanded the types of
${ }^{72}$ Id. at 508 .

${ }^{73} I d$. In addition, citing to the re-enactment rule relied upon by the Court in Textile Mills, the Court in Cammarano stated that:

As was said in Textile Mills, 'the words 'ordinary and necessary' are not so clear and unambiguous in their meaning and application as to leave no room for an interpretative regulation. The numerous cases which have come to this Court on that issue bear witness to that.' In the present cases there is before us regulatory language of more than 40 years' continuous duration expressly providing that sums expended for the activities here involved shall not be considered an ordinary and necessary business expense under the statute. The provisions of the Internal Revenue Code which underlie the Regulations have been repeatedly re-enacted by the Congress without the slightest suggestion that the policy expressed in these regulatory measures does other than precisely conform to its intent.

Id. at 508-09.

${ }^{74} I d$. at $510-11$.
${ }^{75}$ Slee v. Commissioner, 42F.2d 184 (2d Cir. 1930).

${ }^{76} I d$. at 185.

${ }^{77}$ Cammarano at 512.

${ }^{78} I d$. at 513. As discussed, infra, in Part IV, it is not clear that denial of a tax deduction achieves tax neutrality as the Court in Cammarano suggests. Because many of the benefits received by non-business taxpayers from lobbying are not subject to tax, the fact that their lobbying expenditures are non-deductible achieves a certain parity. Charitable organizations receive public subsidies through tax-deductible contributions, and may influence legislation - the provisions of the Code that prevent these organizations from participating in the political process only penalize these organizations when a substantial part of the total activities of the organization are for the purpose of influencing legislation. In other words, incidental (or non-substantial) activities are subsidized. Business taxpayers, however, are taxed on their income, but are prohibited from deducting the lobbying expenditures required to produce that income. This mismatching of income and expense can be seen as placing business taxpayers on a lower footing than non-business taxpayers.

But, see Supplemental and Minority Views of Senators Paul Douglas and Albert Gore, 1962-3 C.B. 1092, 1116-1120. 
expenditures disallowed as deductions-including expenditures for both direct and grassroots lobbying, and the disallowance of a deduction for a portion of dues paid to a membership organization, a substantial part of the activities of which consisted of lobbying. ${ }^{79}$ The regulations issued by the Treasury Department in 1959 raised many administrative and enforcement problems and uncertainties for both the government and taxpayers. ${ }^{80}$ More importantly, however, Congress became concerned with the apparent incongruity between the treatment of expenses for appearances before the different branches of government. ${ }^{81}$ For example, expenses incurred in appearing before legislative bodies or before legislators were not deductible while appearances before executive or administrative officials with respect to administrative matters, or before the courts with respect to judicial matters, were deductible where the expenses otherwise qualify as trade or business expenses.

\section{B. The enactment of Section 162(e) in 1963: Congress steps in}

As part of the Revenue Act of $1962,{ }^{82}$ Congress addressed these issues for the first time by enacting Section 162(e), which provided for a deduction for expenses associated with direct lobbying activities incurred by business taxpayers. ${ }^{83}$

Section 162(e), as enacted in 1963, provided that a taxpayer could deduct all of its ordinary and necessary direct lobbying expenses paid or incurred during the taxable year in carrying on a trade or business. ${ }^{84}$ Specifically, Section 162(e) defined these
${ }^{79}$ T.D. $6435,1960-1$ C.B. 79 , promulgated former Treas. Reg. $\S$ 1.162-15(c)(15), which provided:

$\S 1.162-15$ Excepted Contributions. *** (c) (1) Expenditures for lobbying purposes, for the promotion or defeat of legislation, for political campaign purposes (including the support of or opposition to any candidate for public office), or for carrying on propaganda (including advertising) related to any of the foregoing purposes are not deductible from gross income. For example, the cost of advertising to promote or defeat legislation or to influence the public with respect to the desirability or undesirability of proposed legislation is not deductible as a business expense, even though the legislation may directly affect the taxpayer's business. On the other hand, expenditures for institutional or "good will" advertising which keeps the taxpayer's name before the public are generally deductible as ordinary and necessary business expenses provided the expenditures are related to the patronage the taxpayer might reasonably expect in the future. For example, a deduction will ordinarily be allowed for the cost of advertising which keeps the taxpayer's name before the public in connection with encouraging contributions to such organizations as the Red Cross, the purchase of United States Savings Bonds, or participation in similar causes. In like fashion, expenditures for advertising which present views on economic, financial, social, or other subjects of a general nature but which do not involve any of the activities specified in the first sentence of this subparagraph are deductible if they otherwise meet the requirements of the regulations under section 162 .

(2) Dues and other payments to an organization, such as a labor union or a trade association, which otherwise meet the requirements of the regulations under section 162 , are deductible in full unless a substantial part of the organization's activities consists of one or more of those specified in the first sentence of subparagraph (1) of this paragraph. If a substantial part of the activities of the organization consists of one or more of those so specified, deduction will be allowed only for such portion of such dues and other payments as the taxpayer can clearly establish is attributable to activities other than those so specified. The determination as to whether such specified activities constitute a substantial part of an organization's activities shall be based on all the facts and circumstances. In no event shall special assessments or similar payments (including an increase in dues) made to any organization for any of such specified purposes be deductible.

(3) Expenditures for the promotion or the defeat of legislation include, but shall not be limited to, expenditures for the purpose of attempting to-

(i) Influence members of a legislative body directly or indirectly, by urging or encouraging the public to contact such members for the purpose of proposing, supporting, or opposing legislation, or

(ii) Influence the public to approve or reject a measure in a referendum, initiative, vote on a constitutional amendment, or similar procedure.

${ }^{80}$ H.R. ReP. No. 1447, 87th Cong., 2d Sess. 17 (1962), reprinted in 1962-3 C.B. 402, 421. These problems included the difficulty in determining whether an expense is deductible in general; how to isolate expenses related to legislative matters; in segregating and classifying expenses; in detailed recordkeeping related to such expenditures; and in determining whether such expenses are substantial.

${ }^{81}$ H.R. ReP. No. 1447, 87th Cong., 2d Sess. 17 (1962), reprinted in 1962-3 C.B. 402, 421; S. REP. No. 1881, 87th Cong., 2d Sess. 22 (1962), reprinted in 1962-3 C.B. 703, 728.

${ }^{82}$ Pub. L. 87-834.

${ }^{83}$ H.R. REP. No. 1447, 87th Cong., 2d Sess. 17 (1962), reprinted in 1962-3 C.B. 402, 421; S. ReP. No. 1881, 87th Cong., 2d Sess. 22 (1962), reprinted in 1962-3 C.B. 703, 728.

${ }^{84}$ I.R.C. $§ 162(\mathrm{e})(1)(\mathrm{A})$. 
direct lobbying expenditures as the taxpayer's (1) expenses in direct connection with appearances before, submission of statements to, or sending communications to, the committees, or individual members, of federal, state, or local legislative bodies with respect to legislation or proposed legislation of direct interest to the taxpayer, (2) expenses in direct connection with communication of information between the taxpayer and an organization of which he is a member with respect to legislation or proposed legislation of direct interest to the taxpayer and to such organization. This language is, of course, identical to the language of the local exception that previously appeared so puzzling. ${ }^{85}$

In addition, the portion of dues paid by a taxpayer to any member organizations that were attributable to the expenses of the above activities carried on by such organization were considered to be deductible expenses. ${ }^{86}$ However, deductions for participation or intervention in political campaigns or in grassroots lobbying continued to be nondeductible. ${ }^{87}$

The reasons for effectively overruling the Supreme Court in Cammarano, voiding the Treasury regulations, and overturning decades of past practice, are recorded in the legislative history. The legislative history cites the need for tax parity between expenditures for appearances before the three branches of government, and the desire to arrive at a true reflection of the taxpayer's net income for tax purposes: ${ }^{88}$

It appears anomalous, for example, that expenses incurred in appearing before legislative bodies or before legislators are not deductible while appearances before executive or administrative officials with respect to administrative matters, or before the courts with respect to judicial matters, are deductible where the expenses otherwise qualify as trade or business expenses. Your committee believes that the present bar on deductions with respect to legislative matters must be modified to place presentations to the legislative branch of government on substantially the same footing in this respect as that with the other two coordinate branches of government.

Congress also emphasized the importance of the information Congress obtained from those who lobby legislators:

It also is desirable that taxpayers who have information bearing on the impact of present laws, or proposed legislation, on their trades or businesses not be discouraged in making this information available to the Members of Congress or legislators at other levels of government. The presentation of such information to the legislators is necessary to a proper evaluation on their part of the impact of present or proposed legislation. The deduction of such expenditures on the part of business also is necessary to arrive at a true reflection of their real income for tax purposes. In many cases making sure that legislators are aware of the effect of proposed legislation may be essential to the very existence of a business. ${ }^{89}$

Congress denied the deduction for grassroots lobbying, presumably because such lobbying was directed at changing public opinion, but not at providing information to legislators that legislatures needed to assess legislation. Similarly, political spendingfrom which corporations were still barred at the time-was explicitly excluded as nondeductible.

The 1963 allowances would remain in place for thirty years, until the tax treatment of lobbying expenditures was swept up in the political debate about campaign finance in the early 1990s. In 1991, Congress considered a bill which included a proposal for the public financing of elections through voluntary contributions and the elimination of the tax deduction for lobbying expenditures that was vetoed by President George H.W. Bush. ${ }^{90}$

\footnotetext{
${ }^{85}$ There are several explanations for the local exception, which we elaborate in the next section: (1) path-dependence, (2) the fact that the disallowance was intended to raise taxes and curb the influence of "big business" on the Congress; and (3) the oft-cited legislative rationale that, at the local level, administrative lobbying activities - which are deductible and are not disallowed by Section 162(e) - are not readily distinguishable from legislative lobbying. See 30 Highlights and Documents 3648 (Sept. 22, 1993).

${ }^{86}$ I.R.C. $\S 162(\mathrm{e})(1)(\mathrm{B})$

${ }^{87}$ I.R.C. $\S 162(\mathrm{e})(2)(\mathrm{A}),(\mathrm{B})$.

${ }^{88}$ Id. The Treasury Department opposed Congress' passage of the allowance, arguing that it violated the principle of tax neutrality: "We are not against lobbying. We think lobbying is fine, the more of it the better, because the representatives of the people know what the country wants. We are only saying that the Government should not pay for it." Testimony of Secretary of the Treasury C. Douglas, Hearings on H.R. 10650 Before the S. Comm. on Finance, 87th Cong., 2d Sess. 4,387 (1962).

${ }^{89}$ H.R. ReP. No. 1447 at 17, 87th Cong. 2d Sess. (1962); Sen. REP. No. 1881 at 22-23, 87th Cong. 2d Sess. (1962).

${ }^{90}$ S. 102 d Cong. $§ 405,137$ Cong. Rec. S6546 (daily ed. May 23, 1991).
} 
Then, as part of a larger effort at campaign finance reform, President Bill Clinton, during the 1992 presidential campaign, promised to "eliminate the deduction for special interest lobbying expenses."91 In his initial State of the Union address, on February 17, 1993, President Clinton reiterated that promise:

I'm asking Congress to enact real campaign finance reform. Let's reduce the power of special interests and increase the participation of the people. We should end the tax deduction for special interest lobbying and use the money to help clean up the political system. And we should quickly enact legislation to force lobbyists to disclose their activities. ${ }^{92}$

Section 162(e) was amended shortly thereafter.

Notwithstanding President Clinton's desire to clean up the political process, the legislative history to the Omnibus Reconciliation Act of 1993 identifies increased revenues as the impetus for repealing the deduction for direct lobbying business expenses. The House Ways and Means Committee report on the proposed amendment to Section 162(e) explains that "[i]n the context of deficit reduction legislation, it is appropriate to limit the business deduction for lobbying expenses." 93

\section{ANALYSIS}

In this Part, we examine the various arguments relating to the tax treatment of direct lobbying expenses.

\section{A. The implicit tax subsidy argument}

A persistent argument in the debate has been that providing business taxpayers with a deduction for lobbying expenses is the equivalent of providing those taxpayers with a tax subsidy for those expenditures, and that the only way to provide for governmental tax neutrality is to disallow any deduction. This is the position currently taken by Section 162(e). From a tax perspective, however, this argument is unfounded, because a tax deduction for lobbying expenses merely treats such business expenses on par with other similar expenses of the taxpayer.
As already noted, the Supreme Court in Cammarano expressed concern that providing business taxpayers with a deduction for lobbying expenditures would provide them with a benefit not available to non-business taxpayers. ${ }^{94}$

In the 1963 debates, which ultimately led to the original provision allowing for the deductibility of direct lobbying expenses, Senators Paul Douglas and Albert Gore illustrated the "tax subsidy" argument as follows:

Suppose a measure is being considered, as many have been, involving a proposed change in the standards or testing procedures for food, drugs, or cosmetics. The costs of presenting the views of drug manufacturers and distributors would be deductible. The cost of presentations on behalf of consumers or of disinterested professional or technical advisers would not be. Or suppose that a State legislature is debating a measure designed to decrease stream pollution. Manufacturers who would be adversely affected by its enactment could deduct the cost of opposition. Members of the public interested in pure water for drinking or for

\footnotetext{
${ }^{91}$ Bill Clinton and Al Gore, Putting People First: How We Can All Change America 46 (1992).

${ }^{92} I d$.

${ }^{93}$ H.R. ReP. No. 103-111, 103d Cong., 1st Sess. 221, reprinted in 1993-3 C.B. 167, 235 (1993). While most commentators believe that Section 162(e) was amended primarily to address budgetary concerns, the Treasury Department explains that the tax neutrality rationale discussed in Cammarano was also considered. According to Treasury, a deduction for lobbying expenses "was inappropriate because it subsidized corporations and special interest groups which intervened in the legislative process." See Shannon King, The Lobbying Deduction Disallowance: Policy Considerations, Comparisons, and Structuring Activities Under Amended Section 162(e), 15 VA. Tax Rev. 551, 558 (1996), citing Department of the Treasury, Summary of the Administration's Revenue Proposals 45 (Feb. 1993); Ellen P. Aprill, Regulating the Political Speech of Noncharitable Exempt Organizations After Citizens United, 10 Election L.J. 363, 379 (2011) at n. 124; Jasper L. Cummings, Tax Policy, Social Policy, and Politics: Amending Section 162(e), 93 TAx Notes 226-163 (Nov. 3 1993).

Professor Aprill notes that "Treasury did not explain how the deduction was inappropriate." Ellen P. Aprill, Regulating the Political Speech of Noncharitable Exempt Organizations After Citizens United, 10 Election L.J. 363, 379 (2011) at n. 124.

${ }^{94}$ Supra note 78 and accompanying text.
} 
recreational uses would have to finance their support of the measure entirely from their own pockets. Or, at the local level, a business owner of a piece of real estate could seek advantageous amendment of the local zoning ordinance, deducting the cost of his presentation before the local city council. The owners of nearby residences would not receive this help from the Federal Treasury in preparing the exhibits and briefs necessary for effective opposition.

These are discriminations impossible to justify. ${ }^{95}$

However, both the Court and the Senators failed to take into account that business and nonbusiness taxpayers are not equal in the following respect: Whereas the benefits that accrue to business taxpayers from their lobbying activities result, where successful, in increased income that is subject to tax, nonbusiness taxpayers that achieve their lobbying goals generally receive nontaxable benefits. Symmetry results only where businesses that receive taxable benefits from lobbying receive offsetting tax deductions, while nonbusiness taxpayers cannot deduct lobbying expenditures where the benefits they receive are not taxable.

Take, for example, the situation where solar panel manufacturers lobby Congress to require utilities to allow solar panel users to feed back excess electricity generated by clean energy into the local grid, and to credit those users for the energy based on a set rate schedule. Solar panel manufacturers support such legislation because its passage would increase the sale of their product and, accordingly, result in increased revenues and profits. For those manufacturers, the increased profits would be subject to tax. Businesses that purchase solar panels would also support such legislation because use of solar panels would reduce their electricity costs. Again passage of the legislation would increase the taxable profits of these businesses, which higher profits would be subject to tax. In both cases, these businesses have increased their current expenses (through lobbying expenditures) in order to generate future profits. Section 162 of the Internal Revenue Code generally allows a business taxpayer the ability to offset this additional income with the costs of earning that income. Lobbying expenses should not be treated any differently. However, under current law, Section 162(e) denies the business a deduction for these lobbying costs. Thus, businesses are taxed on the gross amount of additional income which results from these lobbying activities while they, in fact, only receive a net amount of income (i.e., the difference between the increased income earned less the cost of lobbying for the legislation's passage). On the other hand, the benefits resulting to nonbusiness taxpayers from the legislation-lower utility bills and cleaner air-are not taxable. Current law, correctly, denies the taxpayers that receive these benefits, on which tax is not imposed, from deducting the costs that produce these benefits. ${ }^{96}$

The prior example illustrates the asymmetry existing under current law. Business taxpayers are required to use after-tax dollars in order to generate pre-tax income. Nonbusiness taxpayers, on the other hand, use after-tax dollars to create after-tax benefits. The equal footing desired by the Court in Cammarano is achieved only through a deduction for business lobbying when taxpayers are allowed a tax deduction for expenditures that allow them to generate taxable income, but are required to spend after-tax dollars to produce after-tax income or benefits. In that case, each dollar of business profit in the above example could offset a dollar of business lobbying expense. If Section 162(e) were amended to correspond to this maxim, lobbying expenses of business taxpayers would not only be put on the same footing as lobbying expenses of non-business taxpayer, but lobbying expenses of business taxpayers would be put on the

\footnotetext{
${ }^{95}$ Supplemental and Minority Views of Senators Paul Douglas and Albert Gore, 1962-3 C.B. 1092, 1117.

${ }^{96}$ On the other side of the issue, utilities and their customers without solar panels are both likely to oppose such legislation. The utilities will sell less energy and will likely pass on some of the related loss of profits to the consumers, who will therefore face higher utility bills. For these taxpayers, whereas the utility will generate higher profits (which are subject to tax) if the legislation does not pass, the consumers will see no difference in their income tax bills if they are successful in keeping their utility bills lower. The utilities therefore should be able to offset the higher taxable income with the lobbying cost that helps to generate that income, while the consumers should not benefit from a tax deduction where no additional taxable income results.
} 
same footing as other business expenses of those taxpayers.

Finally, as we think about lobbying expenses as either deductible or not deductible, we recognize that most commentators start with the proposition that the federal income tax is a tax on net income. ${ }^{97}$ Denying a deduction for an amount incurred by a taxpayer in carrying on a trade or business is equivalent to taxing gross income. And, although Congress could impose a tax on gross income, our current system does not do so. ${ }^{98}$ With respect to business taxpayers, Section 162(a) allows for the reduction of gross business income by all ordinary and necessary expenses paid or incurred during the taxable year in carrying on a trade or business. By denying a deduction for lobbying expenses, Section 162(e) sets these expenses apart from all other ordinary and necessary business expenses, and distorts the computation of a business taxpayer's taxable income.

\section{B. Public policy arguments}

The fact that the lobbying disallowance cannot be justified from a tax perspective means that it must be grounded in an overriding public policy concern. What this public policy concern is, however, remains inarticulate and confused.

Congress advanced a reasoned rationale for the 1962 legislation: (1) the need for tax parity,
(2) the unjustifiable distinction between the tax treatment of administrative and executive lobbying, on the one hand, and legislative lobbying, on the other hand, and (3) the desirability of receiving information bearing on the impact of present or proposed legislation for business taxpayers. On this basis, Congress narrowly tailored deductions for direct legislative lobbying at all levels of state and local government, but expressly denied such deductions for business spending on political campaigns and grassroots lobbying. ${ }^{99}$ Excepting political campaigns and grassroots lobbying makes sense, if one accepts that there is independent value to the information that Congress receives from business taxpayers through lobbying. In other words, it makes no sense if the only possible use that can be made of the information by legislators is to generate policy wins for those providing it.

The 1993 amendments to Section 162(e), disallowing deductions for direct lobbying at the state and federal level, but retaining the deduction for local lobbying, are much less articulate and do not make the case for such a change. ${ }^{100}$

The House Report justifies the 1993 revisions to 162(e) as primarily designed to raise revenue. ${ }^{101}$ But there are practical and jurisprudential problems with this interpretation. According to projections, the provision was designed to raise approximate
${ }^{97}$ See David I. Walker, Suitable for Framing, 52 WM. \& MARY L. Rev. 1247 (2011), citing ErIK M. Jensen, The TaXing Power: A Reference Guide to the United States ConSTITUtion 118 (2005); Charles A. Borek, The Public Policy Doctrine and Tax Logic: The Need for Consistency in Denying Deductions Arising From Illegal Activities, 22 U. BALT. L. Rev. 45, 48 (1992). See also Griswold, An Argument Against the Doctrine that Deductions Should be Narrowly Construed as a Matter of Legislative Grace, 56 HARv. L. REv. 1142, 1147 (1943) ("Taxation on net, not on gross, income has always been the broad basic policy of our income tax laws... Net income may be defined as what remains out of gross income after subtracting the ordinary and necessary expenses incurred in efforts to obtain or to keep it," citing McDonald v. Commissioner, 323 U.S. 57, 66-67 (1944) (dissenting opinion of Mr. Justice Black).

The Committee Reports that accompanied the 1913 Revenue Act specifically rejected a proposal to limit losses and deductions to those incurred in a legitimate or lawful trade, noting: "The object of this bill is to tax a man's net income; that is to say, what he has at the end of the year after deducting from his receipts his expenditures or losses. It is not to reform men's moral characters; that is not the object of the bill at all. The tax is not levied for the purpose of restraining people from betting on horse races or upon "futures," but the tax is framed for the purpose of making a man pay upon his net income, his actual profit during the year. The law does not care where he got it from, so far as the tax is concerned, although the law may very properly care in another way." 50 CoNG. REC. 3849 (1913) (remarks of Senator Williams). See also J.S SEIDman, Seidman's Legislative History of F Income TaX LAws, 1938-1961 at 994-97 (1938).

${ }^{98}$ Note, Taxability of Gross Income Under the Sixteenth Amendment, 36 Colum. L. Rev. 274, 282 (1936).

${ }^{99}$ Given Congress's deliberate decision not to overturn the, then, 100-year old public policy objections to corporate political spending, but to expressly distinguish such precedent with regard to expensing business lobbying, it becomes clear precisely how extraordinary the Supreme Court's decision to strike down a ban on corporate political spending was in the Citizens United decision.

${ }^{100}$ See H.R. REP. No. 103-213, 103d Cong., 1st Sess. 111-128 (1993).

${ }^{101}$ See, supra, note 54. 
\$635 million during the first five years after its enactment - a modest sum in terms of federal budgeting even twenty years ago. ${ }^{102}$

But more importantly, it is very rarely justified to deny a business taxpayer a deduction on public policy grounds. Before 1969, the Internal Revenue Code itself did not include public policy exceptions to the deductibility for ordinary and necessary business expenses. ${ }^{103}$ The "public policy doctrine" developed under common law-until Congress decided to codify certain exceptions deemed in violation of public policy. The Supreme Court summarized the scope of the public policy doctrine in Commissioner v. Tellier. ${ }^{104}$ In that case, the Court allowed a taxpayer who was engaged in the business of underwriting public stock offerings and purchasing securities for resale to customers to deduct legal fees paid to unsuccessfully defend himself against criminal charges in connection with securities transactions as "ordinary and necessary" business expenses, stating that the public policy doctrine would apply to prohibit a deduction only where allowing the deduction would "frustrate sharply defined national or state policies proscribing particular types of conduct." ${ }^{105}$ National or state policies that are frustrated must be "evidenced by some governmental declaration of them." 106 Finally, according to the Court, the "test on nondeductibility always is the severity and immediacy of the frustration resulting from allowance of the deduction." 107

Congress, of course, is not limited by common law considerations. ${ }^{108}$ But the Internal Revenue Code reflects a similar reluctance to "mix [business taxation with] morals and enforcement against nontax pursuits." ${ }^{109}$ As part of the Tax Reform Act of 1969, Congress enacted three provisions pursuant to which certain ordinary and necessary business expenditures would be denied a deduction. Section 162(c) denied a deduction for the payment of illegal bribes, kickbacks, and other illegal amounts. Section 162(f) prevented a taxpayer from deducting
${ }^{102}$ J. Comm. on TaXation, io3d Cong., Summary of the Revenue Provisions of the Omnibus Budget ReconciliATION ACt OF I993 (H.R. 2264), 34 (JCS-11-93) (Aug. 23, 1993).

As with any legislation, the provisions disallowing a deduction for lobbying expenditures went through many iterations before becoming law. Shortly after his State of the Union Address, the Treasury Department released a narrative summary of the President's proposal and estimated that it would raise approximately $\$ 978$ million over five years. But see Staff of the J. Comm. on Taxation, iozd Cong., Estimated Budget Effects of the Administration's Revenue Proposals Contained in the Fiscal Year I994 Budget (JCX-2-93) (May 4, 1993) (the Joint Committee estimated that President Clinton's proposal would raise only $\$ 873$ million over the same period).

When the House of Representatives passed a version of the budget in the Omnibus Budget Reconciliation Act of 1993 (H.R. 2264), it included a proposal to eliminate the tax deduction for lobbying expenditures estimated to raise approximately $\$ 829$ million over five years. See H.R. ReP. No. 103-111, at 813 (1993). The Senate passed its own version of the budget, including a variation of the provision covering lobbying expenses that was broader in scope and more disadvantageous to business. The Senate's bill was estimated to raise $\$ 1.22$ billion over five years. See Senate Comm. on the Budget, iOzD Cong., Reconciliation Submissions OF THE Instructed Committees Pursuant to the Concurrent Resolution on the Budget 435 (Comm. Print 1993).

${ }^{103}$ S. ReP. No. 552, 91st Cong., 1st Sess. 273 (1968), reprinted in 1969 U.S. Code Cong. \& Admin. News 2027, 2310. The Code did explicitly allow for the deduction of direct lobbying expenses, overturning the Supreme Court's public policy doctrine in that respect in Cammarano and Textile Mills.

${ }^{104} 383$ U.S. 687 (1966).
${ }^{105} I d$. at 694, quoting Commissioner v. Heininger, 320 U.S. 467, 473 (1943).

${ }^{106}$ Id., quoting Lilly v. Commissioner, 343 U.S. 90, 97 (1952). Stanley Surrey has speculated that the reason there were not more tax penalties was that Congress was "wary of mixing morals and enforcement against nontax pursuits." See David I. Walker, Suitable for Framing, 52 WM. \& MARY L. REv. 1247, 1259 (2011) (citing Stanley Surrey, Pathways to TaX Reform: The ConcePt of TAX ExPenditures 336-37 (1973). ${ }^{107} I d$., quoting Tank Truck Rentals $v$. Commissioner, 356 U.S. 30, 35 (1958).

${ }^{108}$ See, e.g., Commissioner v. Tellier, 383 U.S. 687, 693 (1966). With respect to this point generally, and with respect to lobbying expenditures specifically, the Court has stated:

Deduction of expenses falling within the general definition of s 162(a) may, to be sure, be disallowed by specific legislation, since deductions 'are a matter of grace and Congress can, of course, disallow them as it chooses.' Commissioner v. Sullivan, 356 U.S., at 28, 78 S.Ct. at $514 \ldots$ The Court has also given effect to a precise and longstanding Treasury Regulation prohibiting the deduction of a specified category of expenditures; an example is lobbying expenses, whose nondeductibility was supported by considerations not here present. Textile Mills Securities Corp. v. Commissioner, 314 U.S. 326, 62 S.Ct. 272, 86 L.Ed. 249; Cammarano v. United States, 358 U.S. 498, 79 S.Ct. 524, 3 L.Ed.2d 462.

In fact, at the time that the Tax Reform Act of 1969 was enacted, many lobbying and political expenses were nondeductible. However, under the iteration of Section 163(e) that existed at that time, certain direct lobbying expenses paid or incurred in connection with carrying on a trade or business were deductible. Supra notes 81-89 and accompanying text.

${ }^{109}$ Supra note 107. 
fines or similar penalties paid to a governmental entity. Section $162(\mathrm{~g})$ disallowed a deduction for two-thirds of the amount of the treble damages paid under the antitrust laws. By codifying these narrow and specific public policy allowances, Congress preempted courts from denying deductions on public policy grounds. ${ }^{110}$

In each case, the rationale for prohibiting a deduction was that a taxpayer should not receive a tax benefit, or avoid the economic effect of a penalty, for violating a federal or state policy expressly set forth in a statute. Thus, for example, fines paid by American Freightways (a trucking company) for violating a state's maximum weight laws would not be deductible as an ordinary and necessary business expense. Similarly, Wal-Mart should be prohibited from deducting the payment of bribes to Mexican government officials to speed up the process of receiving building permits because such payments violate the Foreign Corrupt Practices Act.

It is certainly hard to see how a revenue raising measure can be considered an overriding public policy concern. Direct lobbying of the type that we argue should be deductible-lobbying coupled with public disclosure of potentially valuable information upon which legislators and the citizenry can base their views - is neither expressly nor implicitly prohibited by any federal or state statute. While the courts, and many others, have long disfavored the idea of business, and in particular, corporate lobbying, such lobbying activities are decidedly not illegal in the same manner as the items that provide for a disallowance of deductions in Sections 162(c), (f), and (g). ${ }^{111}$

To the extent that Section 162(e) was amended in 1993 to reduce business lobbying-which the Clinton Treasury described as "inappropriate because it subsidized corporations and special interest groups which intervened in the legislative process"current law reflects a public policy that is in direct contradiction with the intent to increase legislative lobbying by businesses under the 1962 amendments. ${ }^{112}$ And yet, neither the Clinton Treasury, nor the legislative history, explain why such lobbying is deemed inappropriate. In its 1993 legislative brief, the Clinton Treasury simply falls back on the
${ }^{110}$ See F. Phillip Manns, Jr., Internal Revenue Code Section 162(f): When Does the Payment of Damages to a Government Punish the Payor? 13 VA. TAx Rev. 271, 277 (1993), citing S. ReP. No. 552, 91st Cong., 1st Sess., at 273-76, reprinted in 1969-3 C.B. at 596-98 ("The provision for the denial of the deduction for payments in these situations which are deemed to violate public policy is intended to be all inclusive. Public policy, in other circumstances, generally is not sufficiently clearly defined to justify the disallowance of deductions."). As stated, supra, at note 66 , the legislative history also notes that lobbying expenditures are also covered by tax law.

${ }^{111}$ The authors recognize that, by focusing on the legality or illegality of a particular conduct, it is possible that, in light of the Supreme Court's recent decision in Citizens United and its expansive First Amendment jurisprudence in the campaign finance area, to argue that expenses for grassroots lobbying and political spending by businesses should also be deductible. To do so is beyond the scope of this Article. We do note, however, that prior to this body of law, most of the activities covered by Section 162(e), with the exception of Section 162(e)(1)(A), were prohibited under federal and/or state campaign finance laws.

${ }^{112}$ In this context, it is noteworthy that provisions enacted into the tax code to effect taxpayer behavior often have the opposite effect. A connection can be drawn between Section 162(e) and Section $162(\mathrm{~m})$, which was also enacted as part of the Omnibus Reconciliation Act of 1993 in this regard. Congress enacted Section $162(\mathrm{~m})$ in an attempt to deal with the perceived problem of excessive executive compensation. See Omnibus Budget Reconciliation Act of 1993, Pub. L. No. 103-66, $\S$ 13211(a), 107 Stat. 312, 46971 . The legislative history states that Section $162(\mathrm{~m})$ was motivated by concerns regarding the amount of executive compensation paid by public companies, and that the provision was intended to reduce excessive compensation. See Staff of J. Comm. ON
Taxation, iogTH Cong., Present Law and Background Relating to Executive Compensation 6 (Comm. Print 2006). This provision generally disallows a tax deduction for compensation paid to certain executives of publicly held corporations in excess of $\$ 1$ million unless such compensation is based on performance.

Both Section 162(e) and Section 162(m) were enacted to address similar public policy issues. Section $162(\mathrm{~m})$ was expected to address the agency problem in publicly traded companies. Simply put, where a publicly traded corporation does not have a controlling shareholder, there is a concern that the top corporate executives "have almost complete discretion in management." See Lucian A. Bebchuk and Jesse M. Fried, Executive Compensation as an Agency Problem, 17 J. of Econ. Perspectives 71 (2003), citing Adolf A. Berle, Jr. and Gardiner C. Means, The Modern Corporation And Private Property 139 (1932). Where such an agency problem exists, Professors Bebchuk and Fried have argued that executive compensation is inefficient and excessive. BEBCHUK AND FRIED, Pay Without Performance: The Unfulfilled Promise of Executive Compensation (2004). For a discussion of these arguments and opposing arguments, see Stuart Lazar, The Unreasonable Case for a Reasonable Compensation Standard in the Public Company Context: Why It Is Unreasonable to Insist on Reasonableness, 59 Buff. L. Rev. 937, 944-952 (2011). Their "managerial power" theory states that compensation paid to corporate executives have often "deviated from arm's-length contracting because directors have been influenced by management, sympathetic to executives, insufficiently motivated to bargain over compensation, or simply ineffectual in overseeing compensation." Bebchuk and Fried at 4.

(Continued) 
Supreme Court's reasoning based on tax parity in Cammarano and on Cammarano's general denunciation of lobbying, without giving any serious attention to the 1962 legislative history addressing this issue, or any of the voluminous political science literature on legislative lobbying as an information subsidy accumulated up until that time. This stands in stark contrast to the detailed debate and analysis of the effects of the legislation passed by the Congress in 1963 .

The presumption is that lobbying, and the lobbying deduction, distort the political process in favor of "special interests," as stated by President Clinton. Clinton called for eliminating the deduction as part of a package of campaign finance reforms that would "reduce the power of special interests and increase the participation of the people." ${ }^{113}$ But by treating direct lobbying the same as political spending, the 1993 amendments undercut the reasoned distinction between influencing elections and public opinion, on the one hand, and providing direct lobbying, on the other hand, that the Congress made in 1962. The present statute does not in any way contemplate the desirability of providing Congress with information and equates informing and educating Congress with political spending.

In the following Part, we argue that the 87th Congress and the 111th Congress both had it right—but only in part.

\section{INFORMATION AS A PUBLIC GOOD}

Members of Congress, who labor under evergreater demands on their time and resources, ${ }^{114}$ continue to view lobbyists as invaluable resources who provide them with costly policy information, political intelligence, and support. ${ }^{115}$ This is consistent with "a growing research consensus" which focuses on the roles of lobbyists "in providing information and $[\ldots]$ technical expertise in affecting the terms of a policy debate and the reactions of decision makers to the appeals of advocates." 116 As Richard Briffault notes, lobbying advises legislators about conditions in particular industries, geographic areas, or socio-economic groups; the costs and benefits of proposed laws and regulations; the consequences of the government actions under consideration; and the views of those affected by potential government decisions. ${ }^{117}$ Moreover, this information is important both for legislation and congressional oversight of the federal bureaucracy. ${ }^{118}$

Uncritical versions of the information subsidy theory conclude prematurely that lobbyists thereby provide a collective or public good. Some political scientists have argued that the information conveyed by lobbyists-information that is not otherwise available to the government - can improve the government decision process, thereby improving welfare. ${ }^{119}$ After all, information has public goods characteristics in (footnote ${ }^{112}$ continued.) In his first State of the Union Address, President Clinton stated that one of his goals in pushing for the end of the tax deduction for "special interest lobbying" was a desire to "reduce the power of special interests and increase the participation of the people." See, supra, note 91. President Clinton's concern about increasing the participation of the people has a similar tone to that of Professors Bebchuk and Fried in granting more power to the shareholders - providing a feeling that Section 162(e) and Section 162(m) were designed to combat similar agency problems. Section 162(m) was created to prevent corporate officers from taking a tax deduction when they set their own salary in situations that might be in conflict with their shareholders; Section 162(e) was enacted to prevent business taxpayers from deducting expenses incurred in lobbying the legislature in situations in which those taxpayers are involved influencing the creation of legislation from which they will benefit.

Whether caused by the passage of tax legislation, the result has been the same. Numerous commentators have noted that Section $162(\mathrm{~m})$ has had the unintended consequence of increasing executive compensation at publicly held corporations. See Lazar, at 985. While there is no similar suggestion that Section 162(e) has increased the amount of money being spent on lobbying, there is certainly no suggestion that there is less money being devoted to lobbying in 2013 than there was in 1993.

\footnotetext{
${ }^{113}$ During the 1992 election, $\$ 3.2$ billion were spent on elections, a 19 percent increase over amounts spent in the 1988 election cycle. Ross Perot, who opted out of public funding early in the election, relying on personal funds, garnered over 18 percent of all votes in the election, causing the Republicans to lose the White House. And new regulations requiring, for the first time, the disclosure of soft-money, influenced overall political spending estimates and focused public attention on campaign finance and, in particular, on large donations to the parties. Herbert E. Alexander and Anthony Corrado, FinANCING THE I992 Election 1, 150-51 (1995). The New York Times reported that soft-money had "grown from a relatively inconsequential aspect of Presidential campaigning to a dominant one." Stephen Labaton, The 1992 Campaign: Campaign Finances; Despite Economy, Clinton Sets Record for Funds, N.Y. Times, Oct. 24, 1992.

${ }^{114}$ Roger H. Davidson, Walter J. Oleszek, and Frances E. Lee, Congress and Its Members (2012).

${ }^{115}$ LEVINE, supra note 3.

${ }^{116}$ BAumgarTnER, et al., supra note 1.

${ }^{117}$ Briffault, supra note 9; Sussman, supra note 3.

${ }^{118} I d$.

${ }^{119}$ Richard Ball, Interest Groups, Influence, and Welfare, 7 ECON. \& POL. II9 (I995).
} 
that, once disclosed, anyone can make use of the information for their own purposes. ${ }^{120}$ Lobbying could thus generate positive externalities or spillover effects. ${ }^{121}$ The 87 th Congress appears to have based the deduction for direct lobbying, at least in part, on the view that the information provided by lobbyists helps Congress, as a whole, do a better job. ${ }^{122}$ The view that lobbying provides such an informational public good prevails among many legislators, professionals, and scholars. ${ }^{123}$ Moreover, even sophisticated analyses slide back into language that can easily be misread in this way. ${ }^{124}$ At the naive extreme, however, such a view fails to consider the nature of the information that is provided, to whom it is provided, how, and in what institutional settings.

A substantial portion of the political science literature-descriptive, empirical, and formal-has attended to precisely these questions. ${ }^{125}$ A widely accepted articulation of the "legislative subsidy theory" by Hall and Deardorff, for example, argues that lobbying operates as "a matching grant" of costly information and resources to "the enterprises of strategically selected legislators." 126 Lobbyists do provide critical policy (and other) information to legislators, but primarily to legislators who already agree with them. ${ }^{127}$ "The proximate objective of this strategy is not to change legislators' minds but to assist natural allies in achieving their own, coincident objectives." ${ }^{128}$ While this makes it look $a s$ if the likeminded legislators were working on behalf of the lobbyists' client or interest group, in fact, the legislators are working on behalf of themselves. $^{129}$

Hall and Deardorff provide an alternative to the popular view that lobbyists succeed by pressuring legislators to do their bidding (the "persuasion theory"), or that they can "buy" votes by making campaign contributions (the "exchange theory"). ${ }^{130}$ But, in so doing, Hall and Deardorff (and this literature in general) also call into question the simple view that business lobbying provides an informational public good.

It is not merely, as Hall and Deardorff themselves point out, that "subsidies help legislators to work harder primarily on behalf of the interest that can afford the high costs," that is, the business groups which exhibit a tremendous predominance and imbalance of financial resources in federal lobbying. ${ }^{131}$ Whatever else it does, business lobbying does provide critical information and policy expertise to legislators. Critical information about mar- kets and industry remains critical information, even if resources are lacking to support non-business interests. ${ }^{132}$

What the literature shows, but does not always recognize explicitly, is that information asymmetries and the strategic use of information distort and undermine the value of such information-even assuming that it is all "good information" in the nature of policy expertise, datasets, and scientific analyses that business interests and their lobbyists

${ }^{120}$ See, e.g., WAwro, supra note 16, at 3 .
${ }^{121}$ Hamid Mohtadi and Terri Roe, Growth, Lobbying and Public Goods, 14 European J. Polit. Econ. 453 (1998) (arguing that lobbying by self-motivated individuals may improve welfare when it entails significant spillovers to other citizens that exceed the social cost of lobbying, but concluding that agents lobby either too much or too little).

${ }^{122}$ Supra note 89-90 and accompanying text. See also, Nick Allard, The Seven Deadly Virtues of Lobbyists: What Lawyer Lobbyists Really Do, 13 ELECTION L. J. 210-219 (2014) ("The first thing lobbyists do is provide information to the government to inform its decisions. This is the best understood and most widely discussed functions of lobbyists.").

${ }^{123}$ See LaPira, supra note 22, at 4-8; JefFrey M. Berry, The New Liberalism: The Rising Power of Citizens Groups (1999) (lobbyists "help representatives do a better job as representatives."); Hall and Deardorff, supra note 1, at 81 (stating that most legislators say "lobbyists provide me with information." "They help me do a better job.")

${ }^{124}$ WAWRO, supra note 16, at 2 I ("An LE contributes his or her own resources and coordinates the resources of others to supply [informational] collective goods.").

${ }^{125}$ See, e.g., Hall and Deardorff, supra note 1; BAUMGARTNER ET AL., supra note 1; WAWro supra note 16; Epstein and O'Halloran, supra note 8, Lapira, supra note 22; AustenSmith, supra note 4 for reviews of the literature.

${ }^{126}$ Hall and Deardorff, supra note 1, at 69.

${ }^{127}$ Marie Hojnacki and David C. Kimball, Organized Interests and the Decision of Whom to Lobby in Congress, 42 Ам. Poli. ScI. Rev. 775, 775 (1998) ("most scholars agree that groups lobby their friends in the legislature").

${ }^{128}$ Hall and Deardorff, supra note 1 , at 74 .

${ }^{129} \mathrm{Id}$. at 81 .

${ }^{130}$ It is worth noting that the "exchange theory" in its crudest form has found support among progressive and conservative legal scholars. Richard Posner and William Landes, for example, state that in the legislative process, laws are sold for "campaign contributions, votes, implicit promises of future favors, and sometimes outright bribes." The Independent Judiciary in an Interest Group Perspective, 18 J.L. \& ECON. 875 (1975). This finds no support in any of the empirical literature on Congress, or professional literature on lobbying.

${ }^{131}$ Hall and Deardorff, supra note 1 , at 81.

${ }^{132}$ Policymaking is not a zero-sum game, although it is often treated as such. In this volume, Heather Gerken and Alex Tausanovich argue for a public finance system for lobbying Congress, which would address the problem of financial imbalance. 
are providing. ${ }^{133}$ The information asymmetry between legislators and lobbying interests, which is widely recognized in the literature, ${ }^{134}$ leads to moral hazard. Legislators have limited time and resources to understand or verify the accuracy of the information provided. Business (and other) interests can thus act opportunistically by providing information selectively, or framing complex empirical evidence by self-serving interpretation. Knowing this, legislators will discount valuable information so provided, because they will not be able to assess the quality of the information.

One practical solution to this information asymmetry problem is a type of reputational bonding. ${ }^{135}$ Experienced professionals assert that a lobbyist who provides bad or even deceptive information will be excluded from the process permanently. ${ }^{136}$ This supports the information subsidy theory. But it raises further problems. It suggests that legislators will discount information that is not provided through such lobbyists-like, for example, information coming directly from businesses and corporations-because such information is not bonded in this immediate fashion. And this curious fact, which flies in the face of popular theories of the dominance of business interests, is, in fact, observed. ${ }^{137}$

Other internal mechanisms exist to overcome this information asymmetry problem. Recall that lobbyists do not publicly disclose the information they receive, but provide it to strategically selected legislators. ${ }^{138}$ These legislators, referred to as "legislative entrepreneurs" (LEs) in the literature, specialize in a particular policy area and commit their resources to providing their information and policy expertise to other legislators. ${ }^{139}$ Such LE's either already occupy leading positions on committees and subcommittees, or are motivated by rising in the congressional ranks. ${ }^{140} \mathrm{As}$ a result of greater specialization, such LEs and their staff will be in a better position to assess the value of the information that they receive from businesses and their lobbyists. But this only gives rise to a second set of information asymmetries between LEs and other legislators leading to similar problems. The other legislators, including those with policy expertise in other areas, rely upon the LE's expertise in collecting, filtering, and assembling such information in their particular area of expertise. ${ }^{141}$ To the extent that LE's have their own (personal and policy) goals, their opportunis- tic behavior will include managing information strategically. ${ }^{142}$ Such behavior includes withholding information (in whole or in part), delaying or timing information disclosure to prevent others from making independent use or being able to adequately digest and respond to the information, and structuring legislative debates to avoid certain arguments or make these arguments more difficult

${ }^{133}$ Hall and Deardorff do not, in fact, make this argument in their 2006 article.

${ }^{134}$ See Epstein and O'Halloran, supra note 8.

${ }^{135}$ The same is true for knowledge transfer in market settings. "Markets for knowledge and information ... depend critically on reputation, on repeated interactions, and on trust." Erica Gorga and Michael Halberstam, Knowledge Inputs, Legal Institutions, and Firm Structure: Towards a Knowledge-Based Theory of the Firm, 101 NorTHw. L. Rev. 1123, 1169 (2007); Ashish Arora and Robert P. Merges, Specialized Supply Firms, Property Rights and Firm Boundaries, 13 Indus. \& CoRP. Change 451, 470 (2004).

${ }^{136}$ This is commonplace in the profession. See, e.g., < http:// www.meyersandassociates.com/lobbyist.html > ("A lobbyist's success is based totally on his or her reputation and credibility. Giving bad advice or incorrect information to Congress is quickly noted and long remembered. In the lobby world, you are given only one chance to make a mistake and lose the credibility that's necessary for success.").

${ }^{137}$ Beth L. Leech, Frank R. Baumgartner, Jeffrey M. Berry, Marie Hojnacki, and David C. Kimball, Organized Interests and Issue Definition in Policy Debates, in INTEREST Group Politics 275, 278 (Cigler AND LoOMIS EDS. 2002) ("Corporations are essentially suspect and will often fund work at think tanks because something published under their name has limited credibility").

${ }^{138}$ See also Marie Hojnacki and David C. Kimball, Organized Interests and the Decision of Whom to Lobby in Congress, 42 Am. Poli. Sci. Rev. 775, 775 (1998).

${ }^{139}$ WAWro, supra note 16, at 4-5. See also Leech, et al., supra note 138, at 282 ("Most research produced by interest groups is intended for a smaller audience-key policymakers who have authority over the issue at hand.").

${ }^{140}$ WaWro, supra note 16 . Note that subject matter specialization is much more prevalent in the House of Representatives. Senators, who tend to be generalists are much more reliant on knowledgeable personal and committee staff. WALter J. Oleszek, Congressional Procedures and the Policy Process 30-31 (2014).

${ }^{141}$ WaWro, supra note 16.

${ }^{142}$ Gorga and Halberstam, supra note 136 , at $1168-1170$ (describing moral hazards specific to knowledge resources in firms); see, e.g., OleszeK, et al., supra note 96, at 106 ("Committee jurisdictions are akin to property rights [over issues], and few things in Washington are more closely guarded, or as fervently pursued.") (citing David C. KING, Turf Wars: How Congressional Committees Claim Jurisdiction 11 (1997)). 
for their opponents to make. ${ }^{143}$ Such behavior need not be viewed as unprofessional or unethical, but- to the extent it remains within the rules of the game-a valid tactic to promote ones interests and frame issues for decision in an adversarial system or negotiation. In an adversarial system (or a negotiation) it is the role of the adversary (or counterparty) to make their case.

These are just some of the problems with the assumption of frictionlessness that underlies the view that information provided to Congress through lobbying somehow produces positive externalities and ends up serving the "public interest."

\section{POLICY PROPOSAL}

The standard response to the information problems of imperfect markets is regulation and, in particular, regulation that increases the ready availability of good information. ${ }^{144}$ One example is the securities disclosure regime that was established as part of the second wave of New Deal regulation. These disclosure regimes generally require the disclosure of information both to government officials and directly to consumers. Since the rise of the modern administrative state in the 1930s, disclosure regimes have become a critical and pervasive strategy of public and private lawmaking. Over time, disclosure regimes and information transparency rules have become central to the U.S. regulation of the financial markets, public health, public safety, labor relations, labor conditions, the environment, government integrity, and elections.

To date, however, almost no consideration has been given to address the information asymmetries of lobbying by regulating the scope, tools, and timing of the substantive information and expertise that businesses and their lobbyists provide Congress. There is no requirement or standard for publishing the substance of any information, data, or policy analysis that lobbying provides to legislators or congressional committees. This is not merely true for information that lobbyists share with individual legislators in private meetings. But it also includes their reviews of proposed legislation, proposals for new federal programs or activities, written testimony and materials submitted to congressional committees, pre-introduction research undertaken by various individuals and groups to ensure that a proposed bill avoids unintended consequences, and private com- munications with committee members and staff before and during markup, and with House-Senate conference committee members and staff. ${ }^{145}$

Many of these substantive communications about legislative matters proceed in secrecy. Unlike the administrative comment process, there are almost no rules governing this type of input into the development of legislation. The requirements for disclosing any of this information are limited. Indeed, congressional committees are entitled to draft and mark up legislation relying entirely on this type of ex parte communication, given that there is no requirement that legislation (other than annual budget resolutions) be drafted, in whole or in part, based on hearing testimony. Current lobbying regulations require only lobbyist registration, the disclosure of their clients, the moneys spent on lobbying, a very limited identification of the issues of lobbying concern, and similar information. But such regulation does not target the information problems described above.

If the information that lobbying supplies is critical to lawmaking - and there is good reason to believe so ${ }^{146}$ - then such lobbying should be encouraged, and the information should be treated as the valuable resource that it is. ${ }^{147}$

${ }^{143}$ Leech, et al., supra note 138 , at 285.

${ }^{144}$ As information economics has long established, this does not mean that conditions of perfect information can be approximated.

${ }^{145}$ Walter J. Oleszek, Congressional Lawmaking: A Perspective on Secrecy and Transparency, Congressional Research Service 7-5700, R42108, Nov. 30, 2011.

${ }^{146}$ Public as well as private decision makers, and indeed all organizations, depend on costly knowledge resources to accomplish their goals. Government and the private sector (especially big businesses) spend vast sums of money to generate knowledge and information. Just as "knowledge resources are tantamount to the whole business enterprise," in a knowledge economy, see Gorga and Halberstam, supra note 136, at 1225, knowledge resources are tantamount to the ability of legislators (and government more generally) to generate public policy for a large, complex, modern society with a highly advanced national economy.

${ }^{147}$ We recognize that certain information used in the legislative process may be proprietary and, as a result, firms could suffer a competitive disadvantage, if that information were shared. See Gorga and Halberstam, supra note 136 at 1127 . The proposal does not require the disclosure of all lobbying communications. To the extent that a taxpayer wishes to protect the confidentiality of firm internal information, the ability is retained, though at a cost - the inability to take a tax deduction with respect to such information provided to legislators or their staff. This "nudge" approach avoids the kinds of First Amendment problems that any requirement of information sharing or any prohibition on lobbying would raise. 
As one of the most experienced lobbyists in Washington, DC notes:

If the public's true concern is asymmetry in the system, where some moneyed interests have more lobbying clout, then the answer is to endeavor to afford the underrepresented more lobbying clout. Contrary to conventional wisdom, the counterintuitive solution to the problem of undue influence is more lobbying, not less. Instead of trying to limit the use of expert advocacy, we should find ways to give the less advantaged a louder voice in the legislative and regulatory processes. Universal access to lobbying provides a check on special access and unfair influence and helps to hold lawmakers accountable. Thus, rather than determining ways to restrict lobbying, we should consider ways to increase access to public policy advocacy. ${ }^{148}$

We therefore propose that businesses should be encouraged to provide information to Congress, but only if the information is publicly disclosed in a timely fashion. Not just hearing testimony, but all communications about the substance of a bill with legislators, their staff, and committee staff, should be deductible, so long as the information is disclosed publicly. Activities such as grassroots lobbying, election spending (including the type of issue advertising that the McCain-Feingold Bill defined as "electioneering communications" before the Supreme Court eviscerated the category) should not be deductible. ${ }^{149}$ In short, we believe that some portion of the version of Section 162(e), allowing for a deduction for oral and written testimony submitted to a legislative body, should be reinstated provided that such information is publicly disclosed so that its value can be used by all.

How should such information be disclosed? Ideally, the Library of Congress or the Congressional Research Service would create a database similar to the "JAMES system" that Lee Drutman has proposed in a publication by The Brookings Institution. Drutman conceived of it as a supplement to the current THOMAS System (found at $<$ http:// thomas.loc.gov $>$ ), which makes legislation available online every time a bill is introduced. The JAMES system, however, would function as a kind of "modern variation on notice-and-comment rulemaking for the legislative process," providing a web-based "forum for lobbyists, constituents, and other interested parties to publicly and transparently debate legislation and, in the process, provide congressional staff, journalists, and the public access to the best available arguments, information, and ideas about public policy-all in a way that is easily searchable and sortable." ${ }^{150}$ Different users would use the system differently. Lobbyists would be required to disclose whom they are advocating for. Members of Congress would be entitled to post pages that make the case for a particular bill. The system would also provide a tool for legislators to manage their constituency input in a more sophisticated manner. ${ }^{151}$ A public online forum would be able to aggregate, rank, and escalate comments by individuals.

The many problems associated with such online systems of information management would require careful development based on existing forums such as Wikipedia, using advanced non-SQL languages pioneered by Facebook and Google. ${ }^{152}$ These details are beyond the scope of this article.

${ }^{148}$ Allard, Seven Deadly Sins, supra note 122, at (This issue). Heather K. Gerken and Alex Tausanovich address this issue practically in their provocative proposal for a public financing system for lobbying in this issue. A Public Finance Model for Lobbying: Lobbying, Campaign Finance, and the Privatization of Democracy 13 ELECT. L. J. 75-90 (2014). From a public choice perspective, the puzzle may indeed be why there is so little money in lobbying, given the stakes. Stephen Ansolabehere, John M. de Figueiredo, and James M. Snyder Jr., Why is There so Little Money in U.S. Politics? 17 J. Econ. Perspectives io5 (2003) (raising this question with regard to campaign contributions).

${ }^{149}$ What makes the idea of allowing large businesses to expense lobbying costs objectionable is the connection between lobbying and campaign finance. Where businesses are able to exert undue pressure on legislators with the help of now unlimited campaign spending, and their lobbyists are the very same people who direct large campaign spending, legislators who ultimately ought to decide the issue on the merits will be forced to decide the issue based on their personal desire for reelection. See, e.g., Lessig, supra note 5, at 100-108.

${ }^{150}$ Drutman, supra note 18 , at 5-9.

${ }^{151}$ Lawmakers already employ a variety of high-tech devices and techniques for communicating with constituents. OLESZEK, supra note 140, at 36; Saci Zavattaro, Members Seeing Advantage of Plugging Into Blogosphere, NATIONAL JOURNAL's ConGRESS DAILY AM, October 25, 2005, 8.

${ }^{152}$ The focus of database developers is on integrating data by using software that can integrate many different data sets and data formats from different and previously non-compatible sources that does not require the advance specification of data-fields that was required by SQL languages. See, e.g., Pramod J. Sadalage and Martin Fowler, NoSQL Distilled: A Brief Guide to the Emerging World of Polyglot Peristence (2013). 
How would such publication mitigate current information asymmetry and adverse selection problems? Critical information would become available to all legislators and outside groups. Real-time, online publication would create a forum where such information can be readily vetted, countered, simplified, and considered in its implications by others (including opposing interest groups, academics, the executive, administrative agencies, individuals, and small businesses). This would make it harder to deploy information strategically during the process.

Will the publication of industry specific information and data merely overwhelm the public? Professor Lessig has made a similar argument with regard to the financial disclosure of lobbying activities, ${ }^{153}$ and concludes that "[n]ot only does the "information' revealed not necessarily inform, but the most important influences in the system would not necessarily be revealed." ${ }^{154}$ There are a number of responses to this question. First, and foremost, the disclosure of written lobbying communications is not primarily intended to reveal who influences whom-although it will enhance this type of disclosure as well-but to make public substantive lobbying information so as to increase the public benefit of such information and decrease its private benefits. Second, we cannot see any benefit that accrues to the public from keeping such information secret, given that legislators, who are lobbied, already use it in the legislative process. Third, the broader, educated public generally relies on intermediaries, including journalists, bloggers, professional associations, public interest groups, think tanks, other lobbyists, and academic experts to play an important role in making sense of complex data and public policy information. Especially at the federal level, where legislation has significant consequences nationwide, there are almost always sophisticated coalitions of interests on both sides of any issue. ${ }^{155}$ Thus Lessig's critique of a more limited financial transparency is also unfair because neither journalists nor the broader public need to analyze lists of contributors and their donations by themselves. Intermediaries, like the Center for Responsive Politics' database and website OpenSecrets.org, have specialized in organizing, maintaining, and analyzing such data.

But why give businesses a tax break to do something they do anyway, that is, spend billions of dollars lobbying Congress? As already noted, it is the right thing to do from a tax standpoint. If corporations are spending these dollars, proper tax accounting should allow them to offset those expenses against their revenue in determining taxable income. These and other arguments from a tax perspective have been addressed in the previous section.

Moreover, the assumption that the lobbying deduction would not change behavior is just that. First, we are not arguing that a tax deduction would encourage the creation of more information. Rather, the tax deduction would encourage businesses and their lobbyists to publicize the substantive information they provide legislatorssomething they currently do not do. They would thus come closer to actually providing an informational public good.

Second, such a tax deduction for direct lobbying may also encourage more small and medium-sized business owners to participate more directly in providing information to Congress. The difference between a deductible and an out-of-pocket expense to attend a congressional hearing may make a difference to these parties currently underrepresented in the process.

Finally, regardless of the deductibility or nondeductibility of any particular lobbying expenditure, the money will likely be spent in Washington in any case. But if businesses and their lobbyists can spend it on something that is deductible, as opposed to something that is not, they are likely to choose the type of spending they can expense. Jasper Cummings has suggested that when Congress took away the deduction for direct lobbying, it may have shifted some of that money to other activities. Not allowing the deduction does not draw these expenditures out of the system. It may, however, mean that this money will go to expenditures, such as grassroots lobbying or campaign expenditures which are much more controversial (and which have never been deductible).

Why not simply legislate lobbying disclosure rules for substantive information? Our proposal reflects a compromise. Tying tax breaks for business to disclosure of substantive lobbying information may have a better chance of passage than a mandate

\footnotetext{
${ }^{153}$ Baumgartner et al. supra note 1, at 251-260 (arguing that financial disclosures are insufficient because they provide both too much and too little information).

${ }^{154} I d$. at 260 .

${ }^{155} \mathrm{Id}$.
} 
or other proposed lobbying reforms. It alters the choice architecture of business lobbying to encourage routine disclosure of written lobbying communications; and it puts the management of written lobbying communications via an online transparency and information system like Lee Drutman's "JAMES" system back on the table.

Moreover, relying on a tax deduction to channel information avoids running into First Amendment problems. The political speech of lobbyists and their clients would not be burdened by refusing them a tax deduction under these circumstances.

This is not to say that we would discourage the amendment of Senate and House rules to confer responsibility on legislators, committees, and staffers to ensure that outside information is made available online just like the federal courts now use the PACER system for all court filings and judicial orders. Indeed, Congress has a great interest in such transparency reforms, given the record levels of public distrust it currently engenders. ${ }^{156}$

Why can't legislators turn to government (administrative agencies, the Congressional Research Service) to supply the relevant expertise? Why not simply increase each legislator's legislative staff? Legislators do rely heavily on information provided by executive agencies, but government cannot provide its own feedback. Different sources produce different substantive information. Large reinsurers, for example, will have unparalleled insight into how a tax provision might impact the national reinsurance markets. Moreover, to the extent that legislators lack a clear understanding, it is the private reinsurers who have a compelling incentive, the necessary resources, and the best access to the data, to generate substantive information about the issue in a timely manner. Moreover, the information is not just available for free in the public domain. In the private sector, good information is generally proprietary, costly, and not freely shared with others. ${ }^{157}$

\section{CONCLUSION}

We recognize that the proposed policy does not address all problems associated with the distortion of the legislative process by large moneyed interests. It is a limited, incremental change that we believe is more feasible politically, than other wholesale reforms, such as the American Bar Association's proposed lobbying reforms. Unlike the focus on curbing money in politics, it recognizes the reality that all participants in the process observe: namely, that legislators depend on the costly information that lobbying and lobbyists provide. With this information already part of the system, bringing such information to light only can help improve the legislative process.

Address correspondence to:

Michael Halberstam

SUNY Buffalo Law School

612 O’Brian Hall

Buffalo, NY 14260-1100

E-mail: m.halbers@buffalo.edu

Stuart Lazar

SUNY Buffalo Law School 615 O'Brian Hall

Buffalo, NY 14260-1100

E-mail: slazar@buffalo.edu

\footnotetext{
${ }^{156}$ Professor Lessig reports that "75 percent of Americans believe 'campaign contributions buy results in Congress.' Three to one, with Republicans ( 71 percent) just as convinced of this as Democrats (81 percent)." LAWRENCE Lessig, RePUbliC Lost 132-33 (2012).

${ }^{157}$ Gorga and Halberstam, supra note 136, at 1123-6. Fung et al., supra note 15 , at 33 .
} 